\title{
Akkermansia muciniphila - obiecujący kandydat na probiotyk nowej generacji
}

\author{
Akkermansia muciniphila - a promising candidate for a next generation probiotic
}

Emilia Markowska, Anna Kiersztan*

Zakład Regulacji Metabolizmu, Instytut Biochemii, Wydział Biologii, Uniwersytet Warszawski

Abstrakt

W ostatnich czasach można zaobserwować duży wzrost zainteresowania relacjami między człowiekiem a mikroorganizmami zasiedlającymi jego organizm. Licznie występują w oraz na ciele człowieka, a ich liczba przekracza liczbę komórek ludzkiego organizmu. Udoskonalenie technik badawczych pozwala lepiej zrozumieć molekularne podłoże tych oddziaływań, co być może pozwoli na wykorzystanie w terapiach tych mikroorganizmów, które korzystnie wpływają na organizm człowieka. W artykule podsumowano dotychczasową wiedzę na temat fizjologii licznie występującej w przewodzie pokarmowym bakterii Akkermansia muciniphila i jej wpływu na organizm gospodarza. Opisano właściwości $A$. muciniphila, jej funkcjonowanie w środowisku przewodu pokarmowego oraz relacje (zarówno antagonistyczne jak i symbiotyczne) z innymi tam bytującymi mikroorganizmami. Przedstawiono także mechanizmy oddziaływania $A$. muciniphila na barierę jelitową, układ immunologiczny oraz metabolizm energetyczny gospodarza. Ponadto opisano jej rolę w patogenezie i terapii chorób, w tym m.in. cukrzycy typu 2, nieswoistego zapalenia jelit, zaburzeń neurologicznych, astmy, a także jej wpływ na odpowiedź pacjenta na terapie przeciwnowotworowe oparte na działaniu układu odpornościowego. Duże zainteresowanie tą bakterią, a także przytoczone wyniki badań, w tym tych sprawdzających bezpieczeństwo jej stosowania, wskazują, że $A$. muciniphila może być obiecującym kandydatem na probiotyk nowej generacji. Niewątpliwie jednak przed dopuszczeniem A. muciniphila do powszechnego stosowania konieczne są dalsze badania z udziałem ludzi, a także wnikliwa ocena bezpieczeństwa jej stosowania.

Słowa

Akkermansia muciniphila • Amuc_1100 • probiotyki • mikrobiota jelitowa • bariera jelitowa • krótkołańcuchowe kwasy tłuszczowe - otyłość • cukrzyca typu 2・nieswoiste zapalenie jelit • zaburzenia neurologiczne • terapia anty-PD-1

Otrzymano: 08.10.2020, Zaakceptowano: 09.08.2021

Abstract

Recently, there has been observed a growing interest in the relationship between humans and their microbiota. Microorganisms are present on and inside of the human body, where their number can exceed the average human body cell count. Advanced research techniques allow us to better understand the molecular mechanisms of these interactions. This knowledge gives us the opportunity to use especially these microorganisms that have a positive impact on the human body in therapies and disease prevention. The article summarizes current knowledge about the physiology of the human gut bacterium Akkermansia muciniphila and its interactions with the host. The properties of $A$. muciniphila, its functions in the gastrointestinal tract and the relationship (both antagonistic and symbiotic) with other microorganisms residing are also described. Moreover, the effect of $A$. muciniphila on gut barrier, immune system and energy metabolism are presented. In addition, the role of $A$. muciniphila in pathogenesis and therapy of diseases such as type 2 diabetes, inflammatory bowel disease, neurological disorders and asthma is mentioned, as well as in the patient's response to anticancer therapy based on the activation of the immune system. The great interest in $A$. muciniphila, as well as results of many studies presented in this article, including those evaluating its safety, indicate that $A$. muciniphila might be a promising candidate for a next generation probiotic. However, more studies are undoubtedly needed to assess the safety of $A$. muciniphila before its approving as a probiotic supplement.

\section{Keywords}

Akkermansia muciniphila $\cdot$ Amuc_ $1100 \cdot$ probiotics $\bullet$ gut microbiota $\bullet$ gut barrier $\bullet$ short chain fatty acids $\bullet$ obesity $\bullet$ type 2 diabetes $\cdot$ inflammatory bowel disease $\cdot$ neurological disorders $\bullet$ anti-PD-1 therapy

Received: 08.10.2020, Accepted: 09.08.2021 


\section{Wstęp}

Przez lata rozwoju mikrobiologii dominowało podejście wiążące występowanie mikroorganizmów w i na ciele człowieka $z$ licznymi chorobami i innymi stanami patologicznymi. W dzisiejszych czasach znacząca część badań skupia się na pozytywnych oddziaływaniach między mikrobiotą a człowiekiem. Mikrobiotą określa się zespół wszystkich gatunków tworzących społeczność mikroorganizmów, najczęściej w odniesieniu do konkretnej lokalizacji (np. mikrobiota jelitowa - wszystkie mikroorganizmy występujące w ludzkich jelitach, a więc bakterie, archeony, drożdże i inne grzyby, a często także wirusy) [1]. Bywa zarówno w języku polskim, jak i angielskim, stosowana zamiennie $\mathrm{z}$ terminem mikrobiom. Przez lata liczni badacze formułowali i stosowali różne definicje mikrobiomu, ale w 2020 r. zespół ekspertów z różnych gałęzi mikrobiologii, ustalił wspólną definicję. Według niej mikrobiom to charakterystyczna społeczność mikroorganizmów zasiedlająca precyzyjnie określony obszar cechujący się wyróżnialnymi właściwościami fizykochemicznymi. Przy czym definicja ma obejmować nie tylko mikroorganizmy (mikrobiotę), ale także ich różne struktury pozakomórkowe, metabolity i ruchome elementy genetyczne, tworzące swoistą ekologiczną niszę. Mikrobiom jest więc terminem szerszym, w którym zawiera się mikrobiota [2].

Szacowana liczba komórek bakteryjnych w i na organizmie człowieka wynosi $3,8 \times 10^{13}$, co znacznie przekracza liczbę komórek samego gospodarza (szacowaną na 3,0 x 10 ${ }^{13}$ ) [3]. Miejscem najliczniejszego występowania mikroorganizmów w organizmie człowieka jest jelito grube, a dokładniej okrężnica. Do innych bogatych w nie miejsc (i z tego powodu uwzględnianych w badaniach oddziaływań między mikrobiotą a gospodarzem) należą: płytka nazębna, ślina, skóra i jelito cienkie [3]. Liczne i ścisłe zależności między mikroorganizmami bytującymi w człowieku a nim samym powodują coraz częstsze użycie terminu superorganizm, mające na celu podkreślenie znaczenia mikrobioty w rozwoju człowieka i zachowaniu jego zdrowia.

\section{Powstawanie mikrobioty jelitowej}

Przyjęło się uważać, że płód jest organizmem sterylnym. Jednak możliwe, że komórki bakteryjne, zamieszkujące szyjkę macicy, w trakcie zaplemnienia przedostaną się w głąb układu rozrodczego kobiety i dosięgną komórki jajowej (w chwili zapłodnienia) lub zarodka (na etapie implantacji bądź wczesnego rozwoju embrionalnego). Mimo to mechanizmy odpornościowe działające $\mathrm{w}$ macicy uniemożliwiają utworzenie społeczności bakteryjnej, dlatego nie istnieje mikrobiota macicy, łożyska czy płodu. Pojawia się jednak pytanie, czy nadal można mówić o sterylności, jeśli odnajduje się tam fragmenty bakteryjnego DNA lub pojedyncze komórki bakteryjne [4]. Warto także pamiętać, że mikrobiota matki może mieć pośredni wpływ na rozwój dziecka, przez oddziaływanie z układem odpornościowym matki czy też przez przenikające przez łożysko metabolity mikroorganizmów [5]. Sugeruje się, że niektóre zmiany zachodzące w czasie ciąży w mikrobiocie jelitowej i pochwowej matki mogą mieć znaczenie adaptacyjne, np. umożliwiające dziecku efektywniejsze pobieranie energii z krwi matki [6]. Pierwszy bezpośredni kontakt dziecka $z$ mikroorganizmami następuje $w$ trakcie porodu. Kolejny ważny etap $w$ rozwoju mikrobioty człowieka związany jest ze spożywaniem mleka matki. Prawidłowy rozwój zarówno dziecka, jak i jego mikrobioty jest możliwy dzięki odżywczemu, prebiotycznemu i stymulującemu odporność działaniu substancji zawartych w mleku matki, które w początkach życia człowieka jest jego jedynym pokarmem [4]. Przez pierwsze sześć miesięcy życia, wskutek spożywania mleka matki, dochodzi u niemowląt do takiego ukształtowania mikrobioty jelitowej, które (przez bakteryjne metabolity) promuje rozwój peryferycznych limfocytów T regulatorowych (odpowiedzialnych za hamowanie zbyt silnej bądź wynikającej z autoagresji, odpowiedzi immunologicznej) i przyczynia się tym samym do prawidłowego rozwoju układu odpornościowego [7]. W późniejszym okresie, m.in. w następstwie ząbkowania, niemowlęta nabywają zdolność przyjmowania także pokarmów stałych, co powoduje wzrost różnorodnych mikroorganizmów zasiedlających przewód pokarmowy dziecka, analogicznie do wzrostu różnorodnych substancji przyjmowanych $z$ pożywieniem. Wtedy to też pojawiają się w diecie dziecka pierwsze składniki pokarmowe oporne na trawienie, za których fermentację odpowiedzialne stają się bakterie licznie zasiedlające jelito grube. W wyniku tej fermentacji powstaje wiele metabolitów, takich jak np. krótkołańcuchowe kwasy tłuszczowe (SCFAs, short-chain fatty acids), wpływających korzystnie na metabolizm oraz procesy odpornościowe organizmu gospodarza [4]. Należy przy tym zaznaczyć, że opisana kolonizacja przewodu pokarmowego człowieka przez mikroorganizmy stanowi pewien modelowy przykład i będzie się różnić przebiegiem u dzieci urodzonych przez cesarskie cięcie. Inaczej też będzie się rozwijała mikrobiota jelitowa u niemowląt karmionych sztucznymi mieszankami odżywczymi. Wszelkie komplikacje w czasie ciąży i porodu również mogą wpływać na omówione procesy. Warto wspomnieć, że także w dorosłym życiu rodzaj przyjmowanego pożywienia w dużej mierze determinuje skład ilościowy i jakościowy mikrobioty jelitowej [8].

\section{Probiotyki nowej generacji}

W ostatnich latach rozwój metagenomiki i różnorodnych narzędzi analiz genetycznych przyczynił się do znacznego 
poszerzenia wiedzy o mechanizmach (na poziomie molekularnym) odpowiadających za oddziaływanie metabolitów wytwarzanych przez mikroorganizmy na organizm gospodarza. Spowodowało to wzrost zainteresowania środowisk naukowych tematami związanymi z badaniem potencjalnych zależności między stanem mikrobioty jelitowej (jej składem ilościowym i jakościowym) a rozwojem licznych chorób (w tym chorób cywilizacyjnych, takich jak: otyłość, cukrzyca typu 2 czy zespół metaboliczny). W latach 2013-2017 ukazało się 12900 publikacji naukowych podejmujących te tematy, co stanowiło więcej niż $80 \%$ tego typu prac opublikowanych w ciągu ostatnich 40 lat [1].

Obecnie stosowane w terapiach bakterie o właściwościach probiotycznych (najczęściej z rodzaju Bifidobacterium i Lactobacillus) zaczynają ustępować w badaniach miejsca probiotykom nowej generacji. Dotychczas stosowane probiotyki (takie jak Bifidobacterium spp., Lactobacillus spp.), choć redukują negatywne skutki niektórych chorób i są bezpieczne w stosowaniu, to ich statystyczna skuteczność wydaje się niewielka [9]. Dzięki obecnej wiedzy na temat mikrobioty jelitowej, a także zrozumienia znaczenia zmian w niej zachodzących (stanu dysbiozy) w różnych chorobach i zaburzeniach, pojawiła się alternatywa dla tradycyjnych probiotyków. Coraz częściej podkreśla się znaczenie stosowania bakterii komensalnych jako naturalnego sposobu polepszenia stanu zdrowia pacjentów. Te właśnie mikroorganizmy, przywracające równowagę $w$ jelitach, zyskały miano probiotyków nowej generacji [10]. Ich zastosowanie poprzedzać będą nie tylko dogłębne badania oceniające ich oddziaływanie na organizm gospodarza, ale też badania umożliwiające poprawne zrozumienie mechanizmów patogenezy choroby, w terapii której probiotyk ten będzie stosowany. Dużą przewagę nad tradycyjnymi daje probiotykom nowej generacji założenie, że będą celowane przeciwko konkretnym zaburzeniom [9]. Do potencjalnych kandydatów na probiotyki nowej generacji należy wyizolowana w 2004 r. z próbek kału zdrowych osób Akkermansia muciniphila, stanowiąca 1-4\% bakterii zasiedlających jelita człowieka i bytująca głównie w jelicie grubym [11].

\section{Akkermansia muciniphila - ogólna charakterystyka}

Akkermansia muciniphila została odkryta w 2004 r. na Uniwersytecie Wageningen w Holandii przez Muriel Derrien. Jej nazwa rodzajowa pochodzi od nazwiska mikrobiologa Antoona Akkermansa, a gatunkowa jest związana z preferowanym źródłem pokarmu, którym dla tego organizmu jest mucyna. A. muciniphila należy do typu Verrucomicrobia (tab. 1) i jest jego jedynym znanym przedstawicielem w ludzkim organizmie [12]. Inne bakterie zaliczane do tego samego typu zostały wykryte w różnorodnych ekosystemach, w tym w glebie, gdzie stanowią ok. 10\% wszystkich bakterii [13] i w wodzie [14]. Typ Verrucomicrobia zalicza się do nadtypu (zwanego też kladem) PVC (Planctomycetes, Verrucomicrobia, Chlamydiae) [13]. Szczep typowy A. muciniphila, wyizolowany z ludzkiego przewodu pokarmowego, nosi nazwę Muc ${ }^{\top}[15]$.

A. muciniphila to podłużna, Gram-ujemna, nieruchliwa i nietworząca form przetrwalnikowych bakteria [11]. Oś podłużna komórki wynosi 0,6-1 um (rozmiar zależy od podłoża, na którym bakteria była hodowana). Może występować pojedynczo, w parach, tworzyć krótkie łańcuchy bądź skupiska (ryc. 1) [15]. Badania z użyciem transmisyjnego mikroskopu elektronowego wykazały obecność filamentowych struktur na powierzchni komórki bakterii. Ponadto okazało się, że $A$. muciniphila jest zdolna do usunięcia ze swojej komórki tuszu Indian ink, co może świadczyć, iż owe struktury filamentowe są kapsularnymi polimerami (ryc. 1). Analiza białek błony zewnętrznej umożliwiła zidentyfikowanie białek formujących pilusy i im podobnych [17]. Dalsze badania wykazały, że jedno z tych białek, nazwane Amuc_1100 (kodowane przez klaster genów kodujący również sekretynę pilusów typu czwartego Amuc_1098), odgrywa znaczącą rolę w modulowaniu odpowiedzi immunologicznej organizmu gospodarza [18].

Początkowo A. muciniphila była uznawana za obligatoryjnego beztlenowca, dziś jednak wiadomo, że może nie tylko tolerować obecność nanomolarnego stężenia tlenu, ale wręcz czerpać z niego korzyści dzięki obecności pierwotnego łańcucha oddechowego [18]. W obecności nanomolarnego stężenia tlenu $A$. muciniphila zamiast kwasu octowego zaczyna wytwarzać kwas propionowy, co powoduje wzrost ATP i $\mathrm{NADH}$, a to promuje wzrost A. muciniphila [17]. Informacja ta jest zgodna z tym, iż A. muciniphila kolonizuje błonę śluzową jelita w pobliżu

Tabela 1. Przynależność taksonomiczna A. muciniphila (według [16]).

\begin{tabular}{cc}
\hline Królestwo & Bakterie \\
\hline Typ & Verrucomicrobia \\
Klasa & Verrucomicrobiae \\
Rząd & Verrucomicrobiales \\
Rodzina & Akkermansiaceae \\
Rodzaj & Akkermansia \\
Gatunek & Akkermansia muciniphila \\
\hline
\end{tabular}



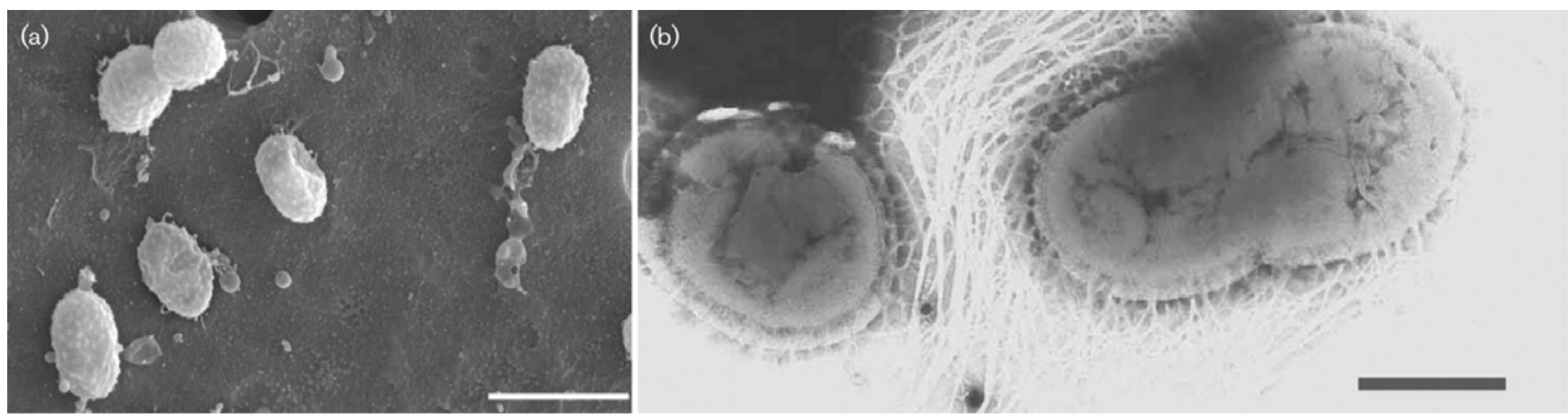

Rycina 1. A. muciniphila, szczep Muc ${ }^{\top}$ : (a) Obraz SEM, podziałka przedstawia $1 \mu \mathrm{m}$. (b) Obraz TEM, podziałka przedstawia 0,5 $\mu$ m, widoczne włókna kapsularne komórki. Według [15], licencja od Copyright Clearance Center, licence ID 1066930-1

komórek nabłonkowych, gdzie występuje niskie stężenie tlenu. Jego tolerancja jest więc jednym z mechanizmów adaptacji bakterii do jej środowiska życia. Innym takim przystosowaniem jest niezdolność do syntezy treoniny. Jest jednym $z$ najliczniej występujących w cząsteczce mucyny aminokwasów, więc rezygnacja z syntetyzowania jej samodzielnie umożliwia bakterii zaoszczędzenie energii [18].

\section{Rozkład mucyny}

Najbardziej charakterystyczną cechą $A$. muciniphila, zapewniającą jej niewątpliwie przewagę nad innymi bakteriami występującymi w przewodzie pokarmowym, jest jej zdolność do rozkładania mucyny - jednego ze składników błony śluzowej jelita. Mucyny są grupą glikoprotein składających się z rdzenia białkowego (bogatego w serynę i reszty treoniny) połączonego poprzez wiązania O- bądź $\mathrm{N}$-glikozydowe $\mathrm{z}$ oligosacharydami. Oligosacharydy te składają się z jednego lub z kilku cukrów prostych (N-acetyloglukozaminy, $\mathrm{N}$-acetylogalaktozaminy, galaktozy lub fukozy), a zakończone są resztą kwasu siarkowego lub resztą kwasu sjalowego (ryc. 2). Rozkładaną mucynę A. muciniphila wykorzystuje jako źródło węgla, azotu oraz energii [15]. Mimo iż A. muciniphila jest zdolna do metabolizowania (zawartych $\mathrm{w}$ danym podłożu) cukrów pochodzących z rozkładu mucyny (np. fukozy), to dużo lepiej rośnie, gdy ma dostęp do całych cząsteczek mucyny [18]. Podejrzewa się, że systemy transportu substratów energetycznych $A$. muciniphila przeznaczone są do transportowania oligosacharydów, a jej metabolizm jest maksymalnie dostosowany do wzrostu na podłożach zawierających cukry złożone [19]. Największy wzrost bakterii obserwuje się na podłożach zawierających $\mathrm{N}$-acetyloglukozaminę i $\mathrm{N}$-acetylogalaktozaminę, jednak gdy bakteria ma dostęp do mieszanki obu cukrów oraz fukozy i glukozy (która nie pochodzi z rozkładu mucyny), w pierwszej kolejności zużywa glukozę i fukozę. Może to wskazywać na ich łatwiejszy transport i większy zysk energetyczny $z$ ich rozkładu oraz sugerować, że aminocukry są dla niej raczej źródłem azotu niż energii [18]. Geny kodujące enzymy odpowiedzialne za rozkład mucyny są konserwowane w genomie nie tylko różnych szczepów A. muciniphila, lecz także różnych gatunków z rodzaju Akkermansia. Podczas jej wzrostu w obecności mucyny liczne geny kodujące hydrolazy glikozydowe i sulfatazy (prawdopodobnie związane $z$ degradacją mucyny) ulegają zwiększonej ekspresji, w porównaniu do wzrostu na glukozie [18].

\section{Występowanie na różnych etapach życia człowieka i w różnych populacjach}

Jak wynika $z$ badań próbek kału zdrowych osób w różnym wieku, $A$. muciniphila jest obecna w przewodzie pokarmowym człowieka na różnych etapach jego życia. Badania próbek znakowanych metodą fluorescencyjnej hybrydyzacji in situ (FISH, fluorescent in situ hybridization) oraz przeprowadzona ilościowa reakcja łańcuchowa polimerazy (qPCR, quantitative polymerase chain reaction) wykazały, że zarówno liczba bakterii spokrewnionych z A. muciniphila, jak i częstość ich występowania w przewodach pokarmowych niemowląt wzrasta znacząco z wiekiem. U 16\% badanych jednomiesięcznych niemowląt wykryto obecność A. muciniphila. Natomiast u półrocznych pacjentów odsetek ten wzrósł aż do $72 \%$. Jednocześnie liczebność $A$. muciniphila u niemowląt, u których wykryto jej obecność, wzrastała z wiekiem (tab. 2). Wspomniane badanie nie sprawdzało jednak korelacji między liczebnością A. muciniphila w przewodzie pokarmowym dziecka a sposobem karmienia go (naturalnym czy też sztucznymi mieszankami). Liczba komórek $A$. muciniphila w układzie pokarmowym wzrasta do 35. roku życia (tab. 2), natomiast w wieku podeszłym (grupa 80-82-latków) zauważono spadek liczebności $A$. muciniphila u $95,5 \%$ badanych [20]. W przeciwieństwie do wieku pacjentów płeć zdaje się nie odgrywać istotnej roli [17].

Analiza próbek kału w ramach projektu Metagenomics of the Human Intestinal Tract (MetaHit), w którym udział 


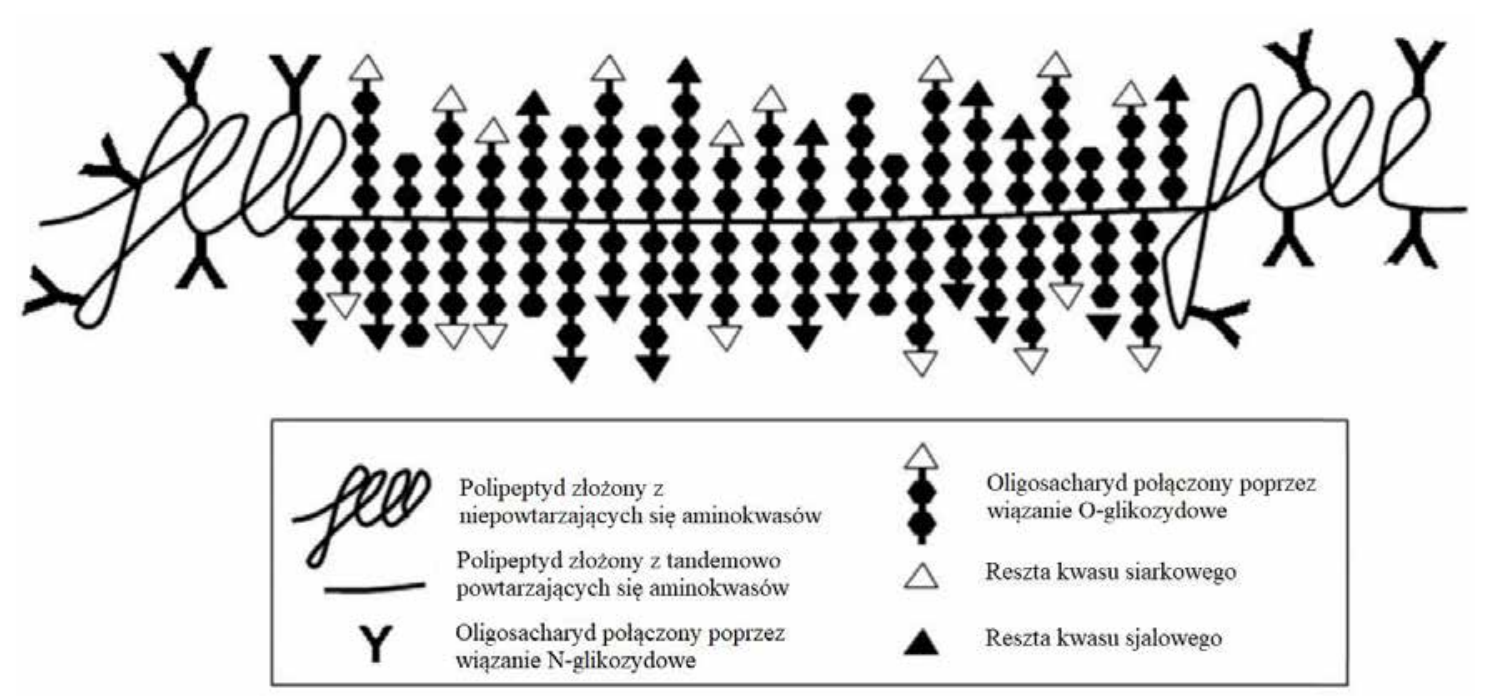

Rycina 2. Cząsteczka mucyny; w części cząsteczki, gdzie oligosacharydy połączone są przez wiązania O-glikozydowe, nie została zachowana skala. Według [14], licencja Creative Commons Attribution-NonCommercial 3.0 Unported License

wzięli Duńczycy i Chińczycy, odkryła różnice w składzie mikrobioty jelitowej zależne od narodowości [17]. Ponadto niedawne badania wykazały, że sekwencje genomowe Verrucomicrobia występują liczniej w próbkach pobranych od osób zamieszkujących bardziej uprzemysłowione obszary w porównaniu z tymi, które zostały pobrane od osób pochodzących z bardziej tradycyjnych populacji zbierackołowieckich, tj. np. ludności Hadza. Należy jednak pamiętać, że liczne analizy porównawcze mikrobioty jelitowej nie są wolne od błędów we wnioskowaniu, wynikających z czynników, takich jak metody zbierania próbek, ekstrakcji DNA i przetwarzania danych [17].

\section{Patogenność}

Ważnym aspektem badań dotyczących $A$. muciniphila jest pytanie o jej ewentualną patogenność. Dotąd nie wykazano żadnych powiązań między metabolizmem A. muciniphila a rozwojem stanów chorobowych [14]. Jednocześnie nadal nie wiadomo, czy $A$. muciniphila w synergii z innymi bakteriami nie jest zdolna do wywołania choroby [12]. Degradacja mucyny jest uznawana za działanie patogenne, gdyż utrata ochronnej błony śluzowej, której jednym ze składników jest mucyna, naraża komórki przewodu pokarmowego na działanie patogenów [15]. Mimo to w przypadku $A$. muciniphila rozkład mucyny jest raczej korzystny, gdyż bierze udział w utrzymaniu równowagi między degradacją a odnową błony śluzowej jelit. Od bakterii o działaniu patogennym A. muciniphila odróżnia się tym, iż bytuje głównie w zewnętrznej błonie śluzowej, a nie sięga, tak jak one, błony wewnętrznej. Jako bakteria Gram-ujemna ma co prawda w błonie lipopolisacharyd, jednak w wypadku A. muciniphila jego występowanie nie zostało powiązane z przypadkami endotoksemii, czyli niebezpiecznej dla życia ogólnoustrojowej reakcji organizmu na zakażenie, za które w innych wypadkach uznawany jest właśnie LPS [12]. Szczep typowy A. muciniphila MucT wykazuje oporność na imipenem, piperacylinę/tazobaktam i doksycyklinę, podczas gdy oporność na wankomycynę, metronidazol i penicylinę G nie została wykazana. Szczep zawiera także geny potencjalnie kodujące beta-laktamazę oraz białko oporności na 5-nitroimidazol [17]. Badania opublikowane w 2020 r. wykazały, że A. muciniphila jest oporna na chloramfenikol, klindamycynę, streptomycynę i erytromycynę [21].

W 2019 r. ukazała się praca podsumowująca pilotażowe (randomizowane, podwójnie zaślepione i zawierające odniesienie do grupy kontrolnej przyjmującej placebo) badania prowadzone w grupie kilkudziesięciu osób z nadwagą lub otyłością i współwystępującą insulinoopornością. Jej autorzy wykazali, że codzienna, trzymiesięczna suplementacja $10^{10}$ żywych lub pasteryzowanych komórek $A$. muciniphila była w pełni bezpieczna i dobrze tolerowana przez te osoby [22]. Zgodnie z obecnym stanem wiedzy wydaje się więc, że A. muciniphila nie zagraża bezpieczeństwu człowieka,

Tabela 2. Liczebność $A$. muciniphila w przewodzie pokarmowym w zależności od wieku człowieka [log komórek/g fekaliów]; według [20]

\begin{tabular}{cc}
\hline Wiek pacjenta & Liczebność $A$. muciniphila \\
\hline 1 miesiąc & $2,05-4,36$ \\
6 miesięcy & $2,50-7,30$ \\
12 miesięcy & $2,80-9,50$ \\
$25-35$ lat & $5,00-8,80$ \\
\hline
\end{tabular}




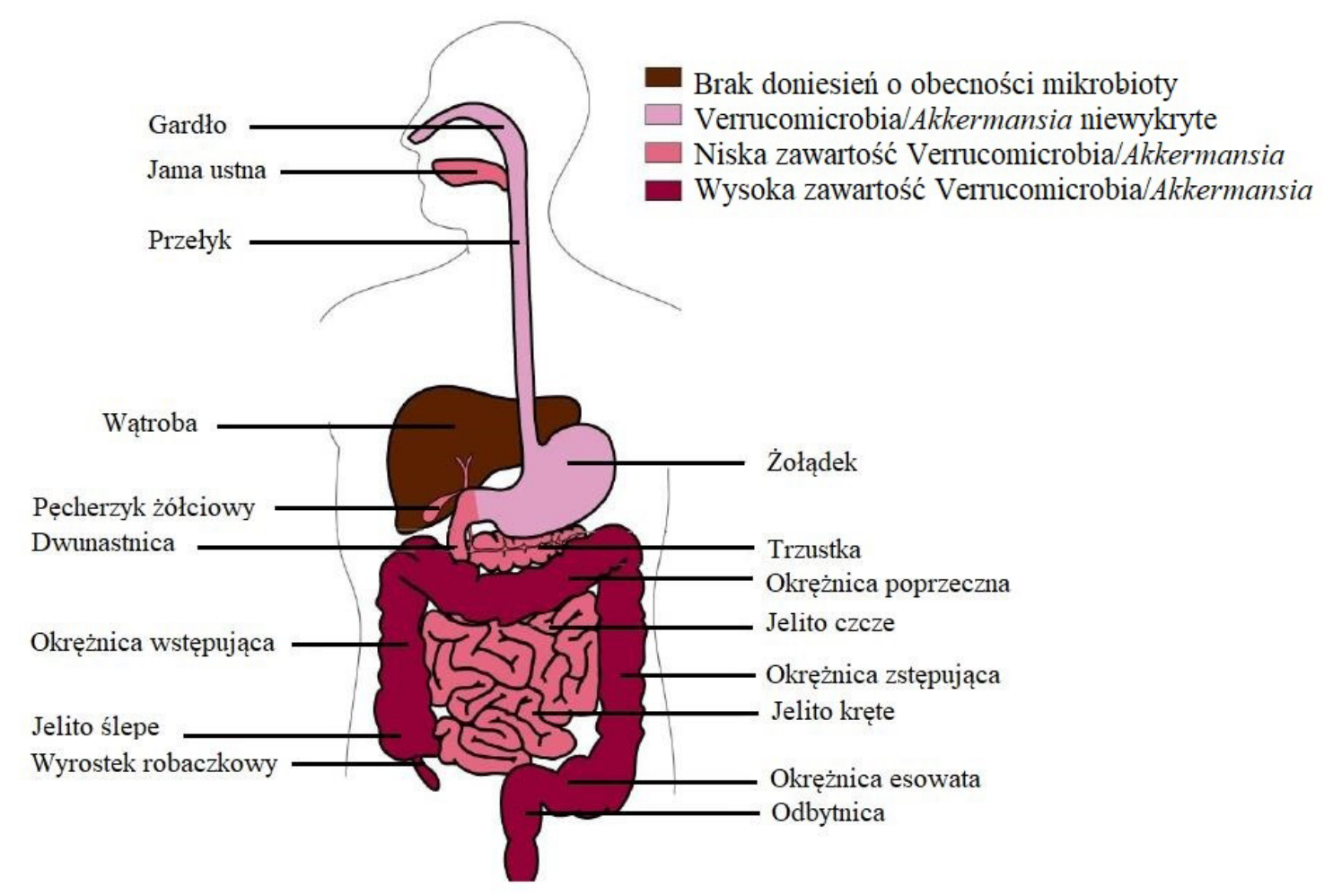

Rycina 3. Przegląd występowania Verrucomicrobia/Akkermansia w przewodzie pokarmowym człowieka. Według [17], licencja Creative Commons Attribution License nr CC BY 4.0

jednak - jak w przypadku każdego kandydata na probiotyk nowej generacji, tak i w przypadku A. muciniphila niezbędne są dalsze pogłębione badania nad jej ewentualną patogennością.

\section{Środowisko życia}

A. muciniphila może wzrastać w temperaturze 20$40^{\circ} \mathrm{C}$ (temperatura optymalna to $37^{\circ} \mathrm{C}$ ) i w pH 5,5-8,0 (optymalne $\mathrm{pH}$ to 6,5). Dlatego też zdolność $A$. muciniphila do przetrwania w soku żołądkowym jest niewielka. Jak wspomniano wcześniej, A. muciniphila jest bakterią bytująca w błonach śluzowych. Wprawdzie to właśnie błona śluzowa jelita grubego tworzy optymalną niszę dla $A$. muciniphila, ale śluz występuje także na innych odcinkach przewodu pokarmowego. Niemniej jednak różnice w temperaturze, $\mathrm{pH}$, stężeniu tlenu i kwasów żółciowych, a także typie mucyny budującej błonę śluzową, wpływają na liczebność $A$. muciniphila zasiedlającej dany odcinek przewodu pokarmowego. Gatunki bakterii wykazujące ponad $97 \%$ zgodność sekwencji 16s rRNA z sekwencją szczepu typowego $A$. muciniphila $M^{\top}{ }^{\top}$ znaleziono m.in. w jamie ustnej, trzustce, drogach żółciowych, jelicie cienkim i wyrostku robaczkowym oraz - wspomnianym wcześniej jelicie grubym (ryc. 3); bakterie te występują także w mleku matki [17].
Zamieszkiwaną przez A. muciniphila błonę śluzową tworzy śluz - lepka wydzielina o charakterze wysoce uwodnionego żelu (ok. 95\% stanowi woda). Składa się przede wszystkim z glikoprotein - mucyn - a także soli, lipidów i białek spełniających funkcje ochronne, takich jak defensyny, czynniki wzrostu, immunoglobuliny, lizozym i wiele innych [14]. Mucyny zazwyczaj są wytwarzane w wyspecjalizowanych komórkach tkanki gruczołowej i komórkach kubkowych układu pokarmowego. Z punktu widzenia biofizyki mucyny odpowiadają za lepko-elastyczny charakter śluzu [14].

Śluz jest nieustannie wydzielany, a następnie degradowany. Proces ten może zająć od kilku minut do wielu godzin, w zależności od tego, w jakim narządzie zachodzi, i od sytuacji, w której znajduje się organizm - np. w razie inwazji patogenów odpowiedź ze strony komórek nabłonka musi być szybka. Grubość i dynamika zmian śluzu różnią się znacznie między narządami. Grubość błony śluzowej żołądka (chroniącej jego komórki przed szkodliwymi warunkami środowiska - wysokim stężeniem kwasu solnego) jest większa niż błony śluzowej jamy ustnej. Jelito cienkie pokryte jest głównie luźno związaną błoną śluzową, która jest najcieńsza w jelicie czczym, gdzie najintensywniej są pobierane substancje odżywcze przez komórki nabłonkowe jelita. W jelicie grubym grubość błony śluzowej zwiększa 
Warstwa zewnettrzna błony śluzowej

Warstwa wewnętrzna błony śluzowej

Nabłonek jelita z komórkami kubkowymi

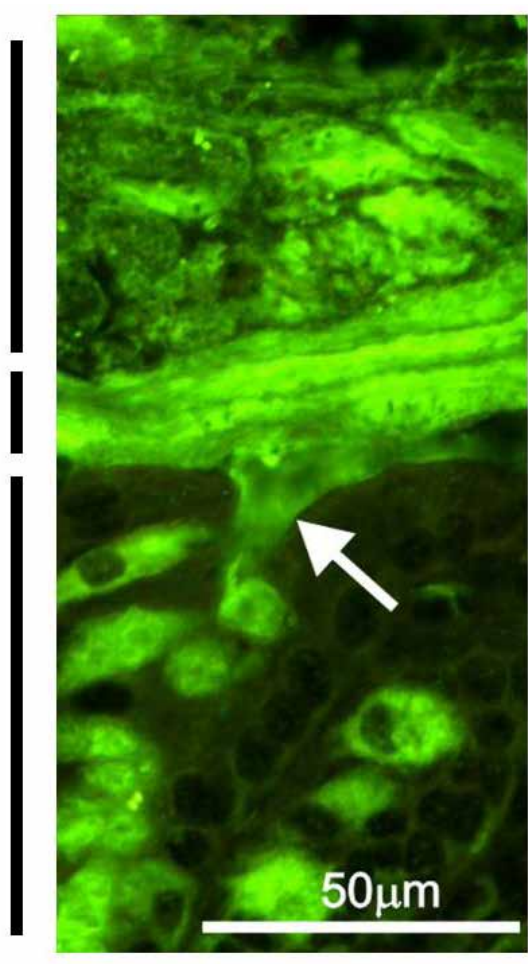

Rycina 4. Warstwy błony śluzowej jelita grubego. Preparat jelita grubego utrwalony w odczynniku Carnoya, a następnie poddany immunologicznemu barwieniu mucyny Muc2 (kolor zielony), która wypełnia obie warstwy błony śluzowej oraz komórki kubkowe nabłonka. Strzałka wskazuje miejsce sekrecji mucyny Muc2 z komórki kubkowej. Według [23]

się stopniowo, poczynając od jelita ślepego, gdzie jest najmniejsza, aż do odbytnicy, gdzie występuje najgrubsza warstwa śluzu [14].

Histochemiczne analizy biopsji jelita grubego wykazały, że jego błona śluzowa składa się de facto z dwóch warstw (ryc. 4). Zewnętrzna warstwa, określona jako mobilna i nieadherentna, jest przede wszystkim rozpuszczalna i nieustannie usuwana. Odpowiada za pozbywanie się potencjalnie niebezpiecznych czynników (mikroorganizmów/ wirusów), które się do niej związały; to właśnie w tej warstwie bytuje A. muciniphila. Warstwa wewnętrzna, nazywana również adherentną, jest ściśle połączona z powierzchnią komórek nabłonkowych i nierozpuszczalna w wodzie. Tworzy selektywną barierę, umożliwiającą transport jedynie małych cząsteczek. Wydaje się, że w okrężnicy warstwa wewnętrzna błony śluzowej nie zawiera żadnych bakterii, mimo iż jej skład jest bardzo zbliżony do składu ruchomej i pełnej bakterii warstwy zewnętrznej (w obu warstwach głównym składnikiem śluzu jest mucyna Muc2). Przyczyna tego zjawiska nie została jeszcze odkryta [14].

Śluz spełnia w organizmie wiele funkcji: działa jako lubrykant, np. w drogach oddechowych czy też w układzie pokarmowym, gdzie ułatwia przepływ pokarmu. Tworzy również selektywną barierę umożliwiającą transport do komórek nabłonka jedynie związków drobnocząsteczkowych, np. składników odżywczych. Jednocześnie zapewnia tym komórkom ochronę przed uszkodzeniem mechanicznym lub kontaktem ze szkodliwymi substancjami natury biologicznej (pepsyna, kwasy organiczne) czy chemicznej (narkotyki, toksyny, metale ciężkie), a także patogennymi bakteriami, wirusami i pasożytami. Inna rola śluzu, której niedawno zaczęto poświęcać więcej uwagi, związana jest z tym, że może być substratem do wzrostu i powierzchnią adhezji dla mikroorganizmów obecnych w świetle przewodu pokarmowego człowieka [15].

Mucyny nie mają żadnych udokumentowanych właściwości antybakteryjnych. Gdyby pełniły w organizmie jedynie funkcję bariery ochronnej, jak przyjęło się początkowo uważać, najprawdopodobniej w toku ewolucji nabyłyby takich właściwości. Zdaje się więc, że rola mucyn jako substratu dla różnych bakterii jest istotniejsza niż dotąd sądzono. Ochronna i prebiotyczna funkcja mucyn wydają się kolidować ze sobą. Dzieje się tak, ponieważ zmiany w strukturze glikoprotein wpływają na ich fizyczne właściwości i podatność na degradację przez enzymy bakteryjne, a przez to na obie wspomniane funkcje mucyny (większa podatność na degradację ułatwia stanie się substratem dla bakterii, ale wpływa niekorzystnie na skuteczność funkcji ochronnej). Mimo to obie funkcje mogą być świetnie zrównoważone w organizmie (tj. regulowane niezależnie od siebie) dzięki występowaniu różnych typów mucyn w różnych odcinkach przewodu pokarmowego, różnicom w fizykochemicznym składzie mucyn (determinowanym przez typ glikozylacji i stopień oligomeryzacji cząsteczek) oraz różnemu komórkowemu umiejscowieniu cząsteczek mucyny (tj. mucyn wydzielanych na zewnątrz komórek lub związanych z błoną komórkową) [14].

\section{Oddziaływania z innymi bakteriami bytującymi w przewodzie pokarmowym}

Bakterie bytujące w śluzie prawdopodobnie mają przewagę nad bakteriami zamieszkującymi światło przewodu pokarmowego. Są bowiem mniej podatne na usunięcie z organizmu wraz z przesuwaniem treści pokarmowej oraz mają zwiększony dostęp do źródeł węgla zapewnionych przez błonę śluzową. Patogeny mogą być wiązane w świetle przewodu pokarmowego przez proteolitycznie zdegradowane mucyny, a następnie usuwane $z$ nimi. Mucyny mogą również wiązać patogeny w błonie śluzowej i dzięki temu uniemożliwiać im dotarcie do nabłonka. Zapobiega to wiązaniu się patogenów z receptorami komórek nabłonkowych i przenikaniu bakterii przez nabłonek, co występuje w razie braku błony śluzowej lub 
bakterii zdolnych do przejścia przez nią (np. Helicobacter pylori). Bakterie niepatogenne mogą występować wolno w świetle przewodu pokarmowego, związane z mucynami w błonie śluzowej lub żyć $w$ śluzie (i być przez niego chronione), nie wykazując żadnych bezpośrednich interakcji z mucynami. Zarówno niektóre bakterie niepatogenne, jak i patogenne mogą degradować proteolitycznie mucynę, co może zachodzić i w błonie śluzowej, i w świetle przewodu pokarmowego. Uwolnione monosacharydy mogą zostać przekształcone przez bakterie niepatogenne w metabolity, takie jak np. SCFAs, które są istotnym źródłem energii dla komórek nabłonka jelita grubego (ryc. 5) [14].

Bakterie kolonizujące błonę śluzową jelit tworzą społeczność pełną zależności o różnym charakterze. Gatunki kluczowe dla tego ekosystemu to te zdolne do degradacji mucyny, którą wykorzystują jako źródło węgla, azotu i energii. Jednak zróżnicowana struktura mucyny powoduje, że większość mikroorganizmów nie może skutecznie pozyskiwać z niej aminokwasów i monosacharydów. Bakterie rezydujące w błonie śluzowej niezdolne do degradacji mucyny muszą więc polegać na aktywności bakterii ją rozkładających, które degradując te złożone cząsteczki, dostarczają im cukrów, węgla i azotu. „Producenci” kwasu masłowego Faecalibacterium prausnitzii, Eubacterium rectale, Roseburia intestinalis i Anaerostipes caccae to przykłady bakterii niezdolnych do degradacji mucyny, ale powszechnie obecnych w błonie śluzowej. Ze względu na to, że kwas masłowy jest źródłem energii dla kolonocytów (komórek nabłonka jelita grubego), jego wytwarzanie przez organizmy występujące w pobliżu komórek nabłonka jest pożyteczne dla gospodarza [18].

Zależności między różnymi producentami kwasu masłowego a $A$. muciniphila wykazano $w$ badaniach in vitro. Degradacja mucyny przez $A$. muciniphila doprowadziła do nagromadzenia w medium kwasu octowego i monosacharydów, które następnie zostały poddane fermentacji do kwasu masłowego przez hodowane jednocześnie A. caccae, F. prausnitzii i Eubacterium hallii. Ponadto jednoczesna hodowla $A$. muciniphila i $E$. hallii na wspólnym podłożu wykazała istnienie mutualistycznej zależności między tymi bakteriami. Bakteria E. hallii wytwarzała pseudowitaminę B12, która jest niezbędna

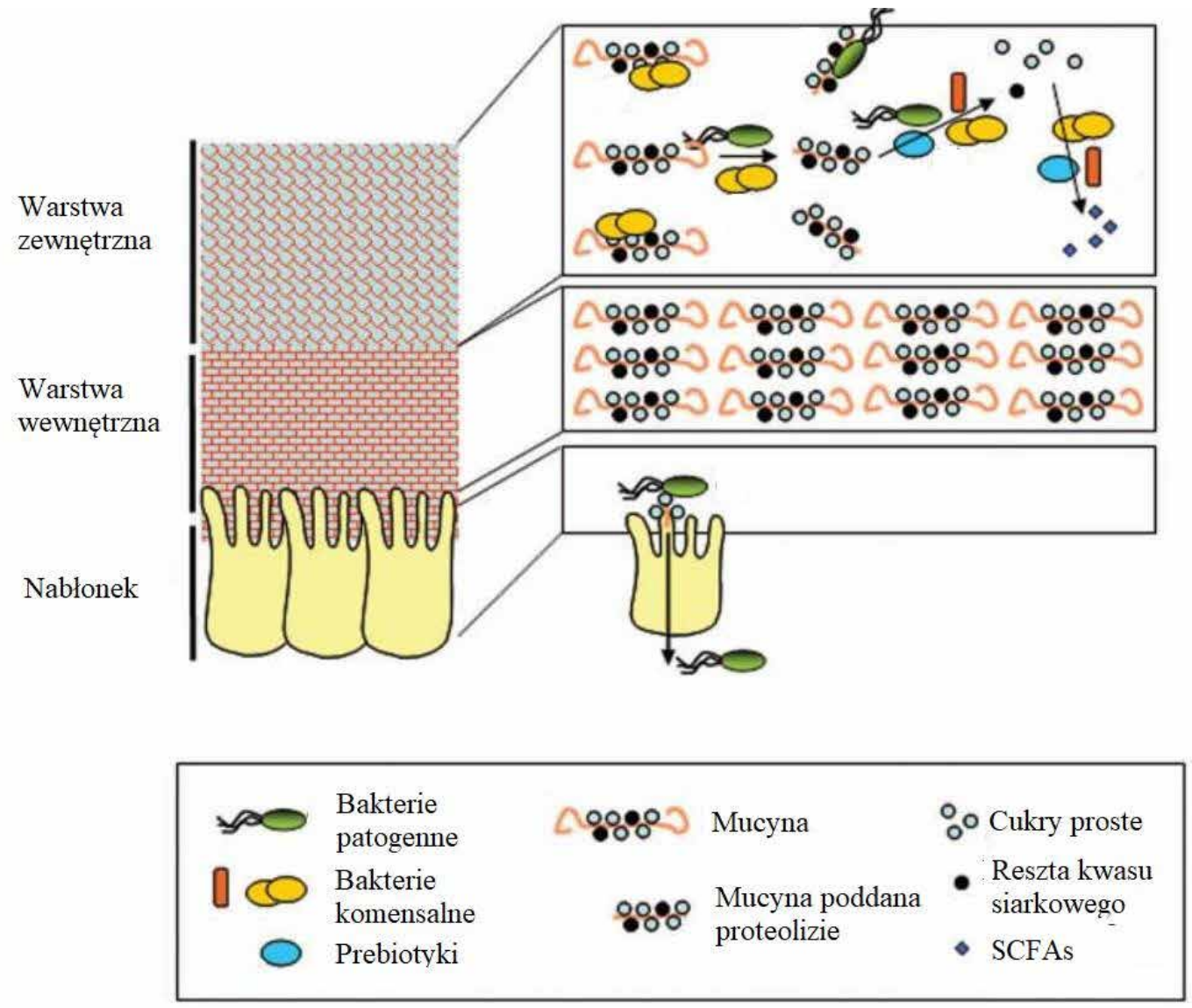

Rycina 5. Różne interakcje między mucynami wchodzącymi w skład błony śluzowej jelita grubego a różnymi rodzajami bakterii. Według [14], licencja Creative Commons Attribution-NonCommercial 3.0 Unported License 
dla $A$. muciniphila do syntezy kwasu propionowego w szlaku metylomalonylowym. Jednocześnie $A$. muciniphila wytwarzała 1,2 propanodiol z fukozy, który $E$. hallii przerabiało na kwas propionowy. Obie te zależności prowadziły więc do syntezy kwasu propionowego, który odgrywa znaczącą rolę w homeostazie jelitowej i utrzymaniu uczucia sytości [18].

W trakcie poszukiwań przyczyn obniżenia liczebności poszczególnych gatunków bakterii komensalnych w przebiegu różnych chorób, postulowano, że jest to związane ze zmianami warunków panujących w układzie pokarmowym, takimi jak zmiany wartości pH czy stężenia soli żółciowych. Niedawno zasugerowano, że także zachwianie relacji ekologicznych między daną bakterią a innymi symbiontami jelitowymi może wpływać na jej liczebność. Wzrost Faecalibacterium prausnitzii, innej bakterii uznawanej za kandydata na probiotyk nowej generacji, jest stymulowany przez kwas octowy, którego producentem jest $A$. muciniphila. Niewiele jednak wiadomo o interakcji między tymi dwoma gatunkami. Badacze analizujący jednoczesne występowanie i korelacje między liczebnością A. muciniphila i F. prausnitzii u osób zdrowych oraz cierpiących na nieswoiste zapalenie jelit (IBD, inflammatory bowel disease) sugerują, że mikroorganizmy te mogą pozostawać w relacji syntroficznej, a zmniejszenie liczebności jednego z nich zmniejsza liczebność drugiego. W ubiegłych latach, mimo iż badania in vitro potwierdziły te zależności, badacze nie znaleźli istotnych korelacji między liczebnością A. muciniphila i F. prausnitzii w organizmach uczestników zdrowych oraz chorujących na jeden z typów IBD - wrzodziejące zapalenie jelita grubego (UC, ulcerative colitis), co wiąże się prawdopodobnie właśnie z tym, że również inne drobnoustroje mogą dostarczać odpowiednich substratów dla $F$. prausnitzii. Pewną korelację między A. muciniphila i F. prausnitzii, świadczącą o podobnych zmianach w ich liczebności, zaobserwowano u osób cierpiących na chorobę Leśniowskiego-Crohna (CD, Crohn's disease). Może się to wiązać z tym, że wzrost obu tych bakterii jest dotkliwie zredukowany przy pH poniżej 5,5. U chorych na IBD (do którego zaliczamy także CD) występują natomiast kwaśne stolce [24]. Zhang i wsp. [25], analizując liczebność $A$. muciniphila i $F$. prausnitzii u osób cierpiących na IBD, zaobserwowali korelację między tymi mikroorganizmami także w grupie kontrolnej u zdrowych ochotników.

Innym przykładem symbiozy między kluczowymi gatunkami mikrobioty błony śluzowej może być efektywne uwalnianie przez $A$. muciniphila siarczanów z mucyny podczas jej degradacji. Są one następnie wykorzystywane przez bakterie redukujące siarczany. Jest to ogromna grupa mikroorganizmów zamieszkujących błonę śluzową, które oddychają beztlenowo, używając siarczanów jako końcowego akceptora elektronów, w wyniku czego powstaje siarkowodór [18]. Chociaż bakterie te najczęściej kojarzone są ze stanem zapalnym, a siarkowodór jest silną genotoksyną i jest przez to wiązany z przypadkami niedziedzicznego raka jelita grubego [26], rzeczywista korelacja między wytwarzaniem siarkowodoru a rozwojem chorób wymaga dalszych badań (zwłaszcza, że siarkowodór odgrywa w organizmie także rolę neuroprzekaźnika). A. muciniphila może sama wykorzystywać siarkowodór do wytwarzania cysteiny, kontrolując w ten sposób jego stężenie i potencjalnie ograniczając toksyczny efekt wywierany przez bakterie wytwarzające siarkowodór na błonę śluzową jelit [18].

A. muciniphila oddziałuje na bakterie patogenne nie tylko przez degradację mucyny (której zdegradowana postać, jak wspomniano wcześniej, ogranicza możliwości działania bakterii patogennych). Przede wszystkim, na zasadzie konkurencji, chroni organizm gospodarza przed inwazją bakterii patogennych. Zwiększa także wytwarzanie białek połączeń ścisłych między komórkami nabłonka (TJs, tight junctions) [27], utrudniając bakteriom patogennym translokację w głąb tkanek. A. muciniphila stymuluje także wydzielanie peptydów antydrobnoustrojowych (AMPs, antimicrobial peptides) i pobudza komórki układu odpornościowego do zwalczania bakterii patogennych. Dokładniejszy opis procesu znajduje się w dalszej części pracy. Przykładem bakterii patogennej, której liczebność spada po doustnym podaniu $A$. muciniphila jest Ruminococcus torques, patogen prozapalny występujący znacznie częściej u pacjentów cierpiących na IBD niż u osób zdrowych. Nie wiadomo jednak, czy jest to wynikiem stymulacji przez $A$. muciniphila do wytwarzania AMPs skierowanych przeciwko Gram-dodatnim bakteriom, do których zalicza się $R$. torques, czy konkurencji o tę samą niszę [28].

\section{Wpływ A. muciniphila na organizm człowieka}

\section{Bariera jelitowa}

Bakterie zamieszkujące ciało człowieka nie tylko tworzą złożone sieci zależności między sobą, lecz także wywierają znaczący wpływ na organizm swojego gospodarza. Pozytywny wpływ $A$. muciniphila (podobnie jak innych przedstawicieli mikrobioty jelitowej) na organizm gospodarza polega przede wszystkim na utrzymaniu integralności zarówno błony śluzowej, jak i komórek nabłonka. $A$. muciniphila wspomaga więc prawidłowe funkcjonowanie bariery jelitowej [12].

Przez barierę jelitową rozumie się funkcjonalną jednostkę, która składa się z dwóch głównych komponentów. 
Pierwszym jest bariera fizyczna zapobiegająca adhezji patogenów i regulująca dyfuzję związków ze światła przewodu pokarmowego, za pośrednictwem krwi, w głąb tkanek gospodarza. Drugim - bariera funkcjonalna, odpowiedzialna za rozróżnianie bakterii patogennych od niepatogennych i za wdrażanie mechanizmów immunologicznej odpowiedzi bądź tolerancji. Bariera jelitowa spełnia swoje funkcje bardzo efektywnie dzięki różnym elementom: odpowiedniej grubości i kompozycji błony śluzowej, obecności TJs i AMPs, limfocytów i innych komórek odporności nabytej oraz wytwarzaniu immunoglobuliny A [1]. Zaburzenia funkcjonowania bariery jelitowej korelują z rozwojem nie tylko wielu chorób układu pokarmowego, lecz także chorób i stanów niezwiązanych bezpośrednio, czy też wyłącznie, z układem pokarmowym, takich jak cukrzyca typu 2, alergie, czy zaburzenia neurologiczne. W związku $z$ tym liczne badania podkreślają rolę probiotyków w redukcji przepuszczalności bariery jelitowej. Wynika to z silnego oddziaływania na nią mikrobioty jelitowej, wpływającej nie tylko na strukturę tej bariery, lecz także na odpowiedź immunologiczną gospodarza [29].

Rozkład mucyny przez A. muciniphila w znacznym stopniu stymuluje jej wytwarzanie, umożliwiając utrzymanie odpowiedniej grubości błony śluzowej jelita. Zmniejszenie populacji $A$. muciniphila może uszczuplić błonę śluzową, osłabiając barierę jelitową i ułatwiając przedostawanie się toksyn lub translokację bakterii patogennych w głąb tkanek [12].

\section{Interakcje z układem odpornościowym gospodarza}

Jak wcześniej wspomniano, na barierę jelitową składa się nie tylko fizyczna bariera złożona z komórek nabłonka i pokrywającej je błony śluzowej, lecz także liczne reakcje organizmu związane $\mathrm{z}$ funkcjonowaniem układu odpornościowego. Recyrkulacja płynów jelitowych i transport limfocytów oraz komórek prezentujących antygen odbywają się w organizmie przez system naczyń limfatycznych łączących centralne narządy limfatyczne (szpik kostny, grasica) z obwodowymi narządami limfatycznymi (m.in. węzłami chłonnymi, śledzioną). Komórki prezentujące antygen są wytwarzane w centralnych narządach odpornościowych i aktywowane w obwodowych. Do tych ostatnich zalicza się także MALT (mucosa associated lymphoid tissue), czyli tkankę limfatyczną związaną z błonami śluzowymi. Jednym z jej typów jest GALT (gut associated lymphoid tissue) - występująca w układzie pokarmowym. Jest zbudowana m.in. z grudek limfatycznych izolowanych (ILFs, isolated lymphoid follicles) [30], złożonych przede wszystkim z limfocytów B i otaczającego je nabłonka [31]

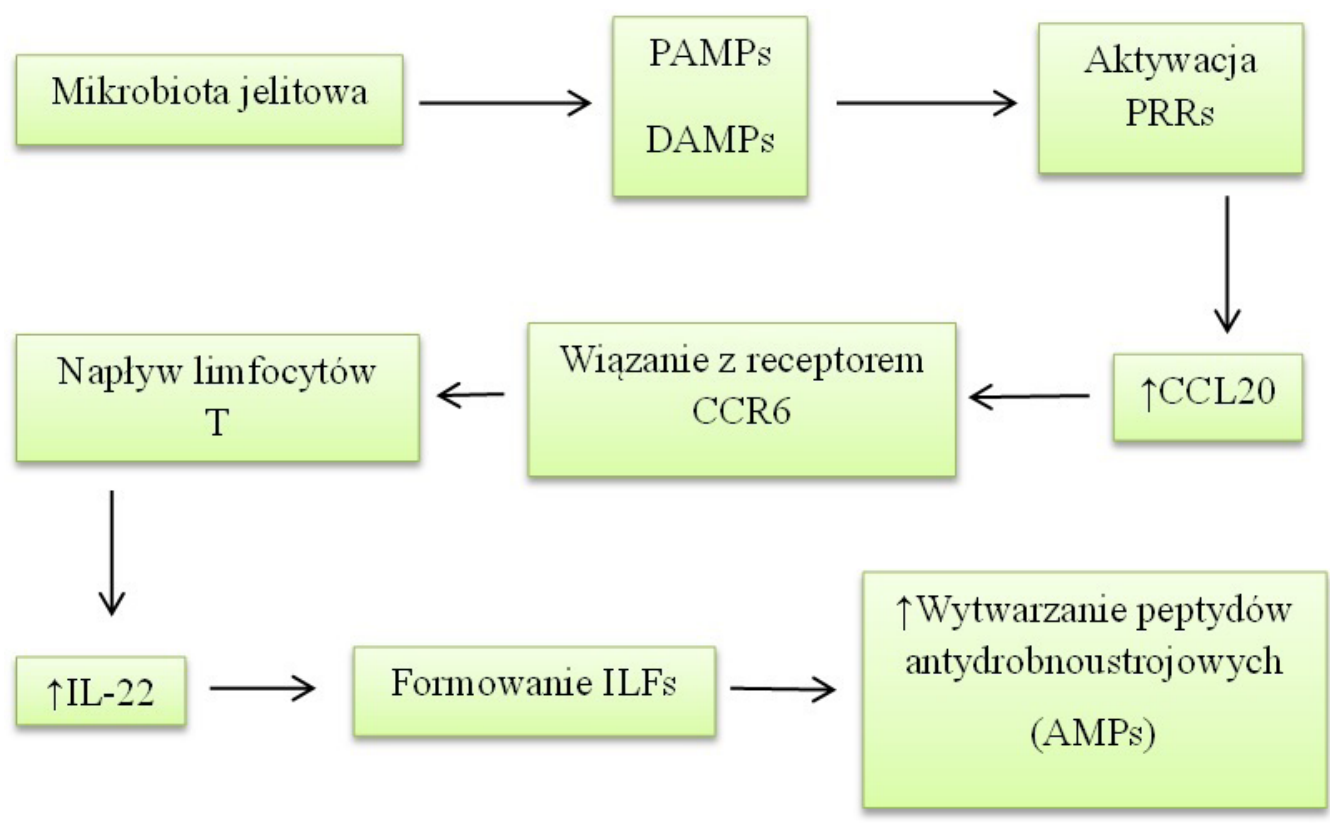

Rycina 6. Ścieżka zależności między mikrobiotą jelitową a układem immunologicznym gospodarza. Aktywacja receptorów z rodziny PRRs przez mikrobiotę jelit rozpoczyna proces prowadzący do formowania ILFs, wskutek tego zwiększa się wytwarzanie AMPs, ograniczających dalszy rozrost mikrobioty. Szczegółowy opis procesu znajduje się w tekście. AMPs - peptydy antydrobnoustrojowe; CCL20 - chemokina 20 należąca do grupy chemokin CC; CCR6 - receptor 6 dla chemokin z grupy CC; DAMPs - wzorce molekularne związane z uszkodzeniem; IL - interleukina; ILFs - grudki limfatyczne izolowane; PAMPs - wzorce molekularne związane z patogenami; PRRs - receptory rozpoznające wzorce molekularne 
oraz kępek Peyera, czyli grudek limfatycznych skupionych [32].

Komórki nabłonka przewodu pokarmowego odgrywają znaczącą rolę w rozpoznawaniu obecności mikroorganizmów i monitorowaniu zmian zachodzących w mikrobiocie jelitowej. Przekazują bowiem informacje do komórek układu odpornościowego przebywających w blaszce właściwej (lamina propria) jelit. Rozpoznawanie mikroorganizmów obecnych w jelitach oraz kontrola zmian zachodzących w mikrobiocie odbywają się głównie dzięki receptorom rozpoznającym wzorce molekularne (PRRs, pattern recognition receptors), do których zalicza się receptory Toll-podobne (TLRs, Toll-like receptors) i receptory NOD-podobne (NLRs, NOD-like receptors). Są to receptory używane przez komórki odporności wrodzonej do wykrywania charakterystycznych elementów komórek bakteryjnych lub bakteryjnych metabolitów, zwanych wzorcami molekularnymi związanymi z patogenami (PAMPs, pathogen associated molecular patterns). Do takich elementów zalicza się m.in. LPS, peptydoglikany, kwasy lipotejchojowe, flagelinę i muramylodipeptydy. PRRs zdolne są także do rozpoznawania wzorców molekularnych związanych z uszkodzeniem (DAMPs, damage associated molecular patterns) powstających w trakcie śmierci komórek i uszkodzenia tkanki w wyniku inwazji patogenów [1].

Aktywacja przez mikrobiotę jelit opisanych wyżej receptorów z rodziny PRRs zwiększa w organizmie sekrecję chemokiny CCL20 (należącej do grupy chemokin CC), która wiąże się następnie z receptorem chemokin 6 (CCR6) (białka z rodziny receptorów chemokin CC) (ryc. 6) [32]. CCR6 to receptor występujący na powierzchni limfocytów $T$ oraz $B$, lecz nieobecny na powierzchni monocytów, granulocytów czy komórek NK [33]. Jest także wysoce eksprymowany w jelitach - w kępkach Peyera i ILFs [34]. Sekrecja CCL20 prowadzi do formowania ILFs z napływających limfocytów T (na powierzchni których eksprymowany był CCR6) [32]. W tych grudkach limfatycznych znaczącym składnikiem sa komórki ILC grupy 3 (ILCs, innate lymphoid cells) - komórki linii limfoidalnej pozbawione rearanżowanych, swoistych antygenowo receptorów (ILCs podzielono na trzy grupy ze względu m.in. na pełnione funkcje) [35]. ILC grupy 3 są głównym źródłem interleukiny 22 (IL-22), która stymuluje komórki nabłonka jelit do wytwarzania AMPs. Zaburzenia formowania ILFs (wynikające z niewystarczającej stymulacji układu immunologicznego przez mikrobiotę) przekładają się więc na niedobór IL-22 i w związku z tym na niedobór AMPs [34]. Tak więc oddziaływania bakterii $z$ gospodarzem oparte na powinowactwie CCR6-CCL20 umożliwiają utrzymanie symbiozy jelitowej. Mikrobiota jelitowa przez stymulację wydzielania CCL20 zapobiega nadmiernemu rozrostowi jej samej bądź populacji bakterii patogennych, do czego mogłoby dojść, gdyby spadło wytwarzanie AMPs.
Bakterie komensalne modulują także pierwotną odpowiedź immunologiczną gospodarza. Stymuluja wytwarzanie homeostatycznej ilości prointerleukiny $1 \mathrm{~b}$ (prolL-1b) przez makrofagi tak, że ich odpowiedź na infekcje występujące w jelitach następuje gwałtowniej. Bakterie niepatogenne odgrywają także rolę w modulacji aktywności limfocytów NKT. Komórki NKT wyrażają jednocześnie receptor TCR charakterystyczny dla limfocytów $T$ oraz receptor charakterystyczny dla komórek NK. Promują stan zapalny przez wydzielanie cytokin: IL-2, IL-4, IL-13, IL-17A, IL-21, czynnika martwicy nowotworu - TNF (tumor necrosis factor) - oraz interferonu gamma (IFN- $\gamma)$. Utrzymanie ich homeostazy, dzięki obecności mikrobioty jelitowej, zapobiega wystąpieniu nasilonej reakcji zapalnej [32].

Odkryto, że $A$. muciniphila ma również wkład w wytwarzanie AMPs w okrężnicy, tj. odpowiada za wytwarzanie Regllly - białka działającego wyłącznie na bakterie Gram-dodatnie i pośredniczącego w ich zabijaniu przez wiązanie się do reszt cukrowych peptydoglikanu eksponowanych na powierzchni komórek bakteryjnych [36]. Stymulacja wytwarzania Regllly ogranicza kolonizację okrężnicy przez bakterie Gram-dodatnie, a następuje aktywacja mechanizmów odpowiedzi immunologicznej indukowanej przez mikrobiotę, zapobiegając powstawaniu nadmiernego stanu zapalnego [37].

Jak już wspomniano, na powierzchni komórki $A$. muciniphila występuje białko Amuc_1100 modulujące sygnalizację międzykomórkową, w której udział bierze TLR2 występujący na powierzchni komórek nabłonkowych, przyczyniając się do wzmocnienia bariery jelitowej. Amuc_1100 powoduje także wzrost wytwarzania przeciwzapalnej cytokiny IL-10 [11]. Istnieją jednak badania wskazujące, że Amuc_1100 jest również zdolne do indukowania wytwarzania cytokin prozapalnych: IL$1 \beta$, IL-6, IL-8 oraz TNF- $\alpha$ w pochodzących $z$ organizmu człowieka „mononuklearnych” (czyli mających okrągłe jądro komórkowe i stanowiących kluczowy element immunologicznej odpowiedzi/tolerancji na mikroorganizmy wnikające do organizmu gospodarza [38]) komórkach z krwi obwodowej (PBMCs, peripheral blood mononuclear cells) [39]. Wykazano jednak, że w porównaniu z E. coli, A. muciniphila wywołuje niewielką stymulację prozapalną, co może mieć istotne znaczenie dla zdrowia, gdyż utrzymuje układ odpornościowy w stanie gotowości, nie wywołując jednocześnie nadmiernego stanu zapalnego [40]. W innym badaniu mierzono m.in. wytwarzanie IL-8 przez ludzkie komórki nabłonka okrężnicy linii HT-29 inkubowane z różną liczbą komórek $A$. muciniphila, $B$. fragilis i $E$. coli. Wykazano silną, zależną od zastosowanej liczby komórek bakterii, reakcję komórek HT-29 na obecność $E$. coli w środowisku oraz zupełny brak reakcji na obecność $B$. fragilis. A. muciniphila w niskich dawkach nie wpływała na 


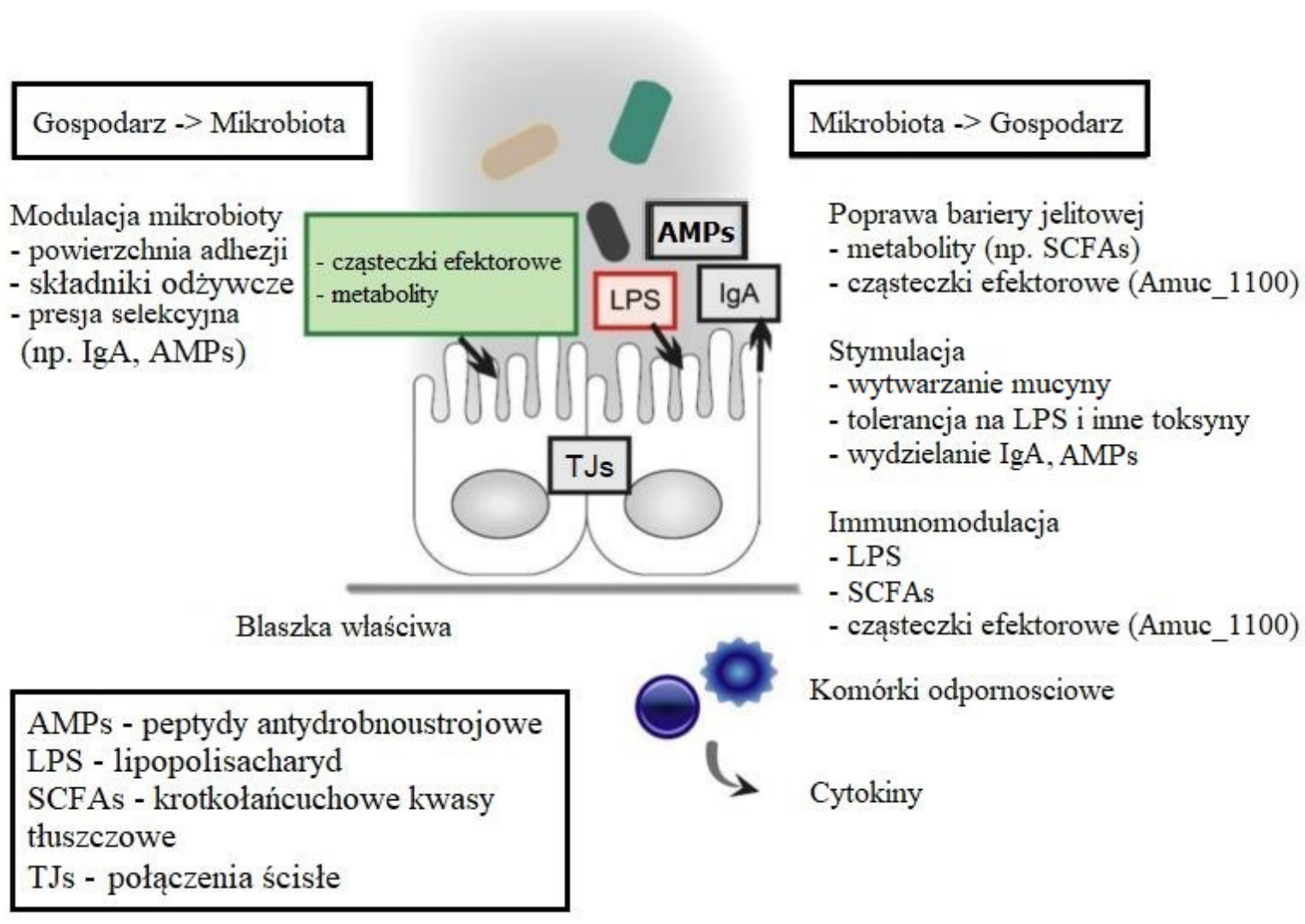

Rycina 7. Schemat podsumowujący interakcje między mikrobiotą a organizmem gospodarza. Według [40], licencja Creative Commons Attribution License nr CC BY 4.0

wytwarzanie IL-8 przez komórki HT-29, natomiast przy najwyższej stosowanej dawce bakterii $\left(10^{6}\right.$ bakterii na $\mathrm{ml}$ stosowanego medium) zauważono wzrost jej wytwarzania. Jednak wydzielanie IL-8 było na poziomie porównywalnym z wywoływanym przez zaledwie $10^{4}$ komórek $E$. coli na $\mathrm{ml}$ [41].

Amuc_1100 może utrzymać swoją aktywność stymulującą TLR2 podczas pasteryzacji $w$ temperaturze poniżej $70^{\circ} \mathrm{C}$, gdyż dopiero $w$ tej temperaturze następuje jego denaturacja [40]. Możliwość użycia w terapii jedynie fragmentów komórek bakteryjnych, bądź komórek poddanych pasteryzacji, a nie całych, żywych mikroorganizmów, może być szczególnie użyteczna w przypadku leczenia pacjentów $\mathrm{z}$ upośledzonymi mechanizmami odpornościowymi [42].

Warto zaznaczyć, że przewód pokarmowy zawiera nie tylko większość mikroorganizmów zamieszkujących organizm człowieka, lecz także gromadzi ogromną liczbę obecnych w ciele człowieka komórek układu odpornościowego. Wywierają one znaczący wpływ na skład mikrobioty, a ich aktywność podlega ciągłej regulacji ze strony mikroorganizmów (ryc. 7). Badania interakcji między mikrobiotą ( $w$ tym A. muciniphila) a komórkami układu odpornościowego doprowadziły do odkrycia jej pierwotnie nieznanych funkcji: np. zauważono, że niektóre komponenty mikroorganizmów przyczyniają się znacząco do regulacji metabolizmu energetycznego oraz utrzymania homeostazy węglowodanowej i lipidowej [1].

Krótkołańcuchowe kwasy tłuszczowe (SCFAs) - produkty metabolizmu A. muciniphila o szczególnym znaczeniu Z licznych metabolitów wytwarzanych przez mikrobiotę niektóre zasługują na szczególną uwagę; są to: kwas foliowy, indole, wtórne kwasy żółciowe, N-tlenek trimetyloaminy (TMAO, trimethylamine-N-oxide), neuroprzekaźniki, tj. serotonina i kwas $y$-aminomasłowy (GABA, gammaaminobutyric acid) i przede wszystkim SCFAs [1]. A. muciniphila dzięki zdolności do rozkładania mucyny, a także dzięki zależnościom, które łączą ją z innymi niepatogennymi bakteriami występującymi w środowisku przewodu pokarmowego, jest bezpośrednim lub pośrednim źródłem wymienionych wyżej SCFAs (zob. rozdział pod tytułem: Oddziaływania $z$ innymi bakteriami bytującymi w przewodzie pokarmowym).

SCFAs, do których zalicza się m.in.: kwas octowy, propionowy i masłowy, mogą pełnić $w$ organizmie funkcję 
cząsteczek sygnałowych, łączących się z receptorami błonowymi związanymi z białkiem G. W nazewnictwie tych receptorów, poza nazwami pochodzącymi od ich ligandów, stosuje się także powszechnie skrót GPR (G protein-coupled receptor) oraz numer receptora. Do takich receptorów zaliczono receptor wolnych kwasów tłuszczowych 3 (FFAR3, free fatty acid receptor 3), zwany także GPR41 oraz receptor niacyny 1 (NIACR1, niacin receptor 1) [43], a także receptor wolnych kwasów tłuszczowych 2 (FFAR2, free fatty acid receptor 2), zwany także GPR43 [1]. Receptory te znaleziono na komórkach nabłonka jelitowego, komórkach odpornościowych i adipocytach [43]. Liczne badania wykazały, że eksprymowany na powierzchni komórek układu odpornościowego GPR43 bierze udział w regulowaniu odpowiedzi zapalnej. GPR43 to receptor związany de facto z dwoma białkami G: $G_{i / o}$ i $G_{q}$. Stymulacja GPR43 przez SCFAs powoduje, poprzez interakcje $z$ białkami rodziny $G_{i / o}$ hamowanie wytwarzania cAMP oraz aktywuje kaskadę kinaz regulowanych przez zewnątrzkomórkowe sygnały (ERK, extracellular signal-regulated kinase), natomiast poprzez interakcję z białkami rodziny $\mathrm{G}_{q}$ zwiększa wewnątrzkomórkowy poziom jonów $\mathrm{Ca}^{2+}$ i promuje aktywację kinazy białkowej aktywowanej mitogenami (MAPK, mitogenactivated protein kinase). Fizjologiczne znaczenie tego podwójnego mechanizmu sygnalizacji GPR43 jest jednak nadal niewyjaśnione [44].

Badania na mysich modelach wykazały, że aktywacja GPR43 za pośrednictwem SCFAs hamowała zależną od insuliny akumulację tłuszczów w tkance tłuszczowej, a zwiększała ich (a także glukozy) wykorzystywanie przez mięśnie szkieletowe. W mięśniach wzrosła także ekspresja genów kodujących białka związane z glikolizą i $\beta$-oksydacją oraz z innymi szlakami zużycia energii. Badania immunocytochemiczne wykazały, że GPR43 (ale także GPR41) jest eksprymowany na powierzchni endokrynnych komórek L jelita, odpowiedzialnych za sekrecję peptydów zaangażowanych w metabolizm glukozy i łaknienie, takich jak glukagonopodobny peptyd 1 (GLP1, glucagon-like peptide-1) i peptyd YY (PYY, peptide YY) [44]. GLP1 jest hormonem inkretynowym wzmacniającym wydzielanie insuliny i hamującym wydzielanie glukagonu w odpowiedzi na przyjęcie pokarmu. Opóźnia także opróżnianie żołądka i zwiększa poczucie sytości [45]. PYY jest natomiast peptydem wydzielanym przez neuroendokrynne komórki jelita krętego i okrężnicy w odpowiedzi na przyjęcie pokarmu. Spowalnia skurcze mięśni gładkich przewodu pokarmowego, zwiększając efektywność trawienia i wchłaniania składników odżywczych, a także absorpcję wody i elektrolitów w okrężnicy [46]. Aktywacja GPR41 również jest związana ze zwiększonym zużyciem energii przez organizm oraz ekspresją leptyny, a także zmniejszeniem podaży pokarmowej (łaknienia) [43].
SCFAs mogą pełnić różne funkcje w organizmie gospodarza - od regulacji poziomu glukozy do efektów immunomodulacyjnych [1]. Wydaje się, że kwas propionowy, także poprzez receptor GPR41, zapobiega występowaniu w organizmie reakcji alergicznych. Warto zaznaczyć, że kwas ten stymuluje także komórki układu odpornościowego do wytwarzania AMPs i w ten sposób może działać jako regulator odpowiedzi odpornościowej, w tym także redukując proliferacje komórek nowotworowych. Kwas propionowy jest zdolny także do „przyuczania” komórek dendrytycznych do osiągnięcia wysokiego potencjału fagocytarnego oraz wpływa na odpowiedź limfocytów Th2 [42]. Ponadto, kwas propionowy, razem z octowym aktywują GPR43 w sposób prowadzący do indukcji chemotaksji neutrofili [43].

Działający analogicznie do niacyny kwas masłowy aktywuje GPR109A. Niacyna znana jest jako czynnik obniżający stężenie tłuszczów: aktywacja GPR109A hamuje hydrolizę trójglicerydów (lipolizę) w adipocytach, a także obniża poziom trójglicerydów i lipoproteiny o niskiej gęstości - LDL (low-density lipoprotein) we krwi, tym samym redukując ich miażdżycogenne działanie [43].

Wykazano, że kwas masłowy stymuluje komórki jelita grubego do oddychania tlenem przez aktywację $\beta$-oksydacji w celu chronienia komórek gospodarza przed ekspansją potencjalnie patogennych bakterii. Ekstremalnie niska ilość tlenu obecna w świetle przewodu pokarmowego (warunki beztlenowe) jest stanem niezbędnym do prewencji ekspansji fakultatywnie anaerobowych patogenów, takich jak Salmonella spp. i Escherichia spp. Konsumpcja tlenu przez komórki gospodarza w procesie $\beta$-oksydacji kwasu masłowego w mitochondriach prowadzi do ograniczonej dyfuzji tlenu z komórek jelita grubego do przedziału światła przewodu pokarmowego, przyczyniając się do utrzymania anaerobowych warunków [1].

Kwas masłowy jest także epigenetycznym regulatorem ekspresji genów - oddziałuje zarówno na metylację DNA, jak i na hiperacetylację histonów. Przez hamowanie deacetylacji histonów kwas masłowy wpływa na różnicowanie komórek Treg (limfocytów T regulatorowych) [42]. Badacze ustalili także, iż kwas masłowy, działając na makrofagi, naśladuje trichostatynę A (TSA, trichostatin A), czyli dobrze scharakteryzowany inhibitor deacetylazy histonowej (HDAC, histone deacetylase). Oba te związki zmniejszają liczbę wydzielanych przez makrofagi cząsteczek prozapalnych: tlenku azotu (II) - NO, IL-6 i IL-12p40 [47]. Przez oddziaływanie zarówno na limfocyty Treg jak i na makrofagi, kwas masłowy odgrywa znaczącą rolę w zapobieganiu wytworzenia stanu zapalnego. Odkryto także, że działając za pośrednictwem HDAC, kwas masłowy wykazuje aktywność przeciwnowotworową [48]. Inhibitory HDAC zatrzymują bowiem cykl komórkowy komórek nowotworowych, indukują ich różnicowanie oraz apoptozę, a także zmniejszają 
angiogenezę i modulują odpowiedź immunologiczną. Czyni je to obiecującymi terapeutykami, zwłaszcza w połączeniu z innymi lekami przeciwnowotworowymi bądź radioterapią [49].

Inaczej niż w przypadku kwasów octowego, propionowego i masłowego, niewiele wiadomo na temat oddziaływania z układem immunologicznym innych SCFAs, takich jak rozgałęzione kwasy tłuszczowe BCFAs (branched chain fatty acids), tj. kwas izomasłowy $i$ izowalerianowy. Są one wspominane $w$ literaturze jako inhibitory HDAC, stąd ich funkcja prawdopodobnie będzie podobna do funkcji kwasu masłowego [42].

Opisany wpływ metabolitów oraz elementów komórkowych A. muciniphila, takich jak białko Amuc_1100, na organizm gospodarza wskazuje na potencjalne korzyści z zastosowania $A$. muciniphila jako probiotyku w terapii różnych chorób metabolicznych, w tym przede wszystkim cukrzycy typu 2.

\section{Zdolność A. muciniphila do autoagregacji}

Dodatkowym argumentem, wskazującym na słuszność zastosowania $A$. muciniphila jako probiotyku, są wyniki badań przeprowadzonych w 2020 r. W czasie tych badań porównywano A. muciniphila i Lactobacillus rhamnosus GG - jeden z najlepiej przebadanych i scharakteryzowanych szczepów bakterii probiotycznych, który jest spożywany na całym świecie jako składnik przeróżnych farmaceutyków i produktów powstałych na bazie sfermentowanego mleka. Jednym z porównywanych parametrów była zdolność bakterii do autoagregacji. Jest to bardzo ważna cecha, gdyż aby przejawiać właściwości probiotyczne, bakterie muszą osiągnąć odpowiednią masę $w$ wyniku agregacji komórek. Jednocześnie zdolność do autoagregacji wydaje się mieć wpływ na adhezję bakterii do komórek nabłonka gospodarza. W porównaniu z Lb. rhamnosus GG badany szczep A. muciniphila DSM 22959 nie tylko wykazał się nieco wyższym procentem agregacji komórek po 24 godzinach, ale także proces autoagregacji następował szybciej, co najlepiej widać, porównując procent autoagregacji obu szczepów po 2 h inkubacji. Wyniki te sugerują, iż $A$. muciniphila DSM 22959 może być równie skutecznym probiotykiem jak stosowany powszechnie $L b$. rhamnosus GG [21].

\section{Potencjalne zastosowanie $A$. muciniphila w terapii różnych chorób}

Duże zainteresowanie $A$. muciniphila przekłada się na liczne badania naukowe skupiające się zarówno na korelacjach między liczebnością $A$. muciniphila w organizmie a różnymi chorobami i terapiami, jak i na poszukiwaniu związków przyczynowo-skutkowych tych zjawisk.

\section{A. muciniphila a cukrzyca typu 2 i zaburzenia do niej prowadzące}

Najwięcej uwagi badacze zdają się poświęcać relacjom między A. muciniphila a stanami chorobowymi związanymi ze zmianami w metabolizmie cukrów i tłuszczów. Jest to ważne, jeżeli weźmie się pod uwagę, jak powszechne w społeczeństwie są tego rodzaju zaburzenia. W 2014 r., wg danych Głównego Urzędu Statystycznego, w Polsce zbyt dużą masę ciała miała już co druga osoba dorosła, tj. ponad $62 \%$ ogółu mężczyzn (44\% stanowili mężczyźni z nadwagą, $18 \%$ otyli) oraz $46 \%$ ogółu kobiet ( $30 \%$ stanowiły kobiety z nadwagą, $16 \%$ otyłe) [50]. Otyłość jest głównym czynnikiem ryzyka rozwoju powszechnych schorzeń, takich jak cukrzyca typu 2, zespół metaboliczny oraz choroby sercowo-naczyniowe, które są główną przyczyną zgonów w krajach rozwiniętych [51].

Cukrzyca typu 2, czyli najczęstszy typ cukrzycy, to chroniczne zaburzenie metaboliczne stanowiące poważny problem zdrowotny na całym świecie. Wraz ze wzrostem liczby ludności i starzeniem się społeczeństwa liczba przypadków cukrzycy w latach 1980-2014 wzrosła ze 108 do 422 milionów. Prognozy zaś mówią, że w 2030 r. powikłania cukrzycy typu 2 stanowić będą siódmą główną przyczynę zgonów. Mimo że różne farmakologiczne metody leczenia cukrzycy są powszechnie dostępne, a ich działanie znacznie poprawia poziom życia osób chorych, to niestety ich stosowanie często wiąże się z występowaniem działań niepożądanych. Stąd w pierwszej kolejności zalecana jest odpowiednia dieta i zwiększenie aktywności fizycznej. Najnowsze badania podkreślają rolę mikrobioty jelitowej w trawieniu pokarmu oraz syntezie kluczowych metabolitów [52]. Wielu badaczy określa mikrobiotę jelitową jako kluczowy element organizmu modyfikujący metabolizm glukozy i lipidów, a zaburzenia w jej składzie mogą prowadzić do rozwoju otyłości i jej progresji do cukrzycy typu 2 [51].

W rozwoju otyłości i insulinooporności znaczącą rolę odgrywają zmiany proporcji między gatunkami mikrobioty. Początkowy zwiększony (w porównaniu z osobami o prawidłowej masie ciała) stosunek Firmicutes/Bacteroidetes i mniejsza liczebność Bacteroidetes, zaobserwowane zostały np. u 12 otyłych osób: dorosłych mężczyzn i kobiet, które następnie losowo przyporządkowano do grup przestrzegających niskotłuszczowej lub niskowęglowodanowej diety przez rok. Stosunek Firmicutes/Bacteroidetes wrócił do normy u osób, które w trakcie trwania badania uzyskały i utrzymały spadek masy ciała [53].

Również dieta powszechna w krajach zachodnich, czyli wysokotłuszczowa oraz wysokowęglowodanowa, 
przyczynia się do zmian w składzie mikrobioty jelitowej i może powodować dysbiozę jelitową, prowadząc przede wszystkim do proliferacji bakterii Gram-ujemnych, takich jak Enterobacteriaceae. Zjawisko to powoduje lokalny stan zapalny i zwiększa przepuszczalność bariery jelitowej [51]. Badacze wielokrotnie obserwowali także korelację między liczbą $A$. muciniphila u myszy a otyłością i cukrzycą typu 2 wywołaną u tych zwierząt zarówno przez czynniki genetyczne, jak i przez dietę wysokotłuszczowo-wysokowęglowodanową. A. muciniphila jest u takich myszy obecna w znacząco mniejszej liczbie, niż u myszy kontrolnych. Dodatkowo u myszy tych liczebność A. muciniphila koreluje odwrotnie $z$ masą ciała, masą tkanki tłuszczowej, występowaniem stanu zapalnego, opornością na insulinę i nietolerancją glukozy [1]. Liczebność A. muciniphila zmniejsza się także progresywnie wraz z wydłużaniem karmienia myszy dietą wysokotłuszczową (HFD, high fat diet). Liczebność tej bakterii spada, zanim pokażą się inne symptomy insulinooporności, co sugeruje związek przyczynowo-skutkowy między obniżonym poziomem A. muciniphila a rozwojem choroby [51]. Jednocześnie wielokrotnie udowodniono, że karmienie myszy prebiotykami (inuliną i jej podobnymi fruktanami oraz polifenolami) znacznie podnosi liczebność $A$. muciniphila i pozytywnie wpływa na regulację zaburzeń metabolicznych związanych z otyłością, w tym zmniejsza masę ciała, oporność tkanek na insulinę, stłuszczenie wątroby oraz wspiera prawidłowe funkcjonowanie bariery jelitowej. Ważne, że również u ludzi liczebność $A$. muciniphila spada w przypadku stanów patologicznych, takich jak: otyłość, cukrzyca typu 2, nadciśnienie, hipercholesterolemia i choroby wątroby. Stosowanie metforminy, czyli jednego z najczęściej używanych leków przeciwcukrzycowych, lub przebycie operacji bariatrycznej wiążą się natomiast ze znacznym zwiększeniem ilości $A$. muciniphila [1].

Informacje te, choć liczne, stanowią jednak nadal jedynie opis korelacji. Stąd wielu badaczy przeprowadza badania in vivo $\mathrm{w}$ różnych modelach zwierzęcych celem zgłębienia zależności przyczynowo-skutkowych między $A$. muciniphila a zdrowiem ludzkim. Badania te wskazują, że podawanie zwierzętom $A$. muciniphila obniża masę ciała, przyrost tkanki tłuszczowej, stłuszczenie wątroby, stan zapalny, poziom cholesterolu i częstość występowania miażdżycy oraz poprawia odpowiedź organizmu na insulinę [1]. Co ważne, podawanie białka Amuc_1100 (bądź odpowiednio pasteryzowanych komórek $A$. muciniphila) myszom karmionym HFD obniżało ich całkowitą masę ciała oraz masę tkanki tłuszczowej. Ponadto skorygowało wywołany tą dietą wzrost średnicy komórek tłuszczowych i hipercholesterolemię oraz poprawiło tolerancję glukozy u tych myszy [40]. Białko Amuc_1100 wykazujące zdolności immunomodulacyjne zdaje się także opóźniać wystąpienie cukrzycy typu 1 u zwierząt ze skłonnością do jej rozwinięcia [1].

Z prozdrowotnym działaniem $A$. muciniphila na organizm człowieka wiąże się jej mechanizm odpowiedzi na zmieniające się w stanach patologicznych warunki środowiska. Analizy transkryptomu wykazały, że większość genów kodujących enzymy związane z degradacją mucyny jest wydajniej eksprymowana w obecności mucyny, natomiast w warunkach jej braku wydajniejszej ekspresji ulegają geny związane z glikolizą i energetycznymi szlakami metabolicznymi. Brak mucyny w podłożu, na którym hodowano komórki $A$. muciniphila, powodował zwiększoną ekspresję zarówno 79 genów kodujących białka wydzielane na zewnątrz komórki, do których zaliczamy Amuc_1100, jak i genów kodujących białka tworzące systemy odpowiedzialne za ich sekrecję. Znając probiotyczne właściwości białka Amuc_1100, przeanalizowano to, jak zawartość mucyny w środowisku wpływa na probiotyczne funkcje $A$. muciniphila. Aby potwierdzić, iż brak mucyny zwiększa efekt wywierany przez $A$. muciniphila na otyłość wywołaną HFD, porównano wyniki terapii z użyciem $A$. muciniphila hodowanej uprzednio na podłożu opartym na mucynie (muc+) lub pozbawionym mucyny (muc-). Myszy na HFD już po 6 tygodniach miały o 15\% większą masę ciała i o $12 \%$ większą zawartość glukozy we krwi na czczo niż myszy kontrolne karmione zwykłą karmą, co wskazuje, że HFD faktycznie prowadzi do rozwoju otyłości i zwiększa poziom glukozy we krwi. Następnie myszom tym codziennie przez 4 tygodnie podawano $A$. muciniphila muclub $A$. muciniphila muc+. Zaobserwowano, że podawanie myszom $A$. muciniphila muc- spowodowało zahamowanie postępu zmian wywołanych przez HFD bardziej efektywnie niż A. muciniphila muc+. Myszy traktowane A. muciniphila muc- charakteryzowały się także istotnie statystycznie mniejszym poziomem trójglicerydów wątrobowych niż myszy traktowane A. muciniphila muc+. Aby sprawdzić, jak $A$. muciniphila wpływa na tolerancję glukozy i insulinooporność, przeprowadzono po 4 tygodniach podawania A. muciniphila dootrzewnowy test tolerancji glukozy (IP-GTT, intraperitoneal glucose tolerance test) oraz test tolerancji insuliny (IP-ITT, intraperitoneal insulin tolerance test). Myszy HFD miały wyższe stężenie glukozy we krwi oraz insuliny w osoczu w porównaniu z myszami z grupy kontrolnej, zarówno na czczo, jak i podczas pomiarów glukozy w teście IP-GTT, co sugerowało spadek tolerancji glukozy na skutek HFD. Myszy na HFD traktowane następnie przez 4 tygodnie $A$. muciniphila muc- wykazały znaczną poprawę tolerancji glukozy i wrażliwości na insulinę. Długie stosowanie HFD u myszy spowodowało także zredukowanie zagęszczenia komórek kubkowych w jelitach. Natomiast podawanie $A$. muciniphila muc- spowodowało przywrócenie prawidłowego zagęszczenia tych komórek. $\mathrm{Na}$ podstawie wyników 
tych badań można wnioskować, iż uszczuplenie błony śluzowej (a więc warunki analogiczne do zastosowanych w laboratorium w trakcie hodowli $A$. muciniphila muc-) występujące w przebiegu otyłości czy cukrzycy indukuje ekspresję białek odpowiedzialnych za probiotyczne działanie A. muciniphila [54].

Jak już wspomniano wcześniej, u bakterii hodowanych na podłożach niezawierających mucyny wzrosła (względem bakterii hodowanych na podłożach zawierających mucynę) ekspresja genów kodujących 78 innych, podobnych do Amuc_1100, białek błony zewnętrznej A. muciniphila. Wyniki te mogą sugerować, iż białka te także wykazują działanie probiotyczne. Nadal jednak nie wiemy dokładnie, jak ekspresja wspomnianych genów regulowana jest w nieustannie zmieniającym się środowisku błony śluzowej jelit [54].

W 2019 r. przeprowadzono wspomniane już wcześniej (zob. rozdział pod tytułem „Patogenność”) badanie wpływu suplementacji $A$. muciniphila na stan zdrowia osób z nadwagą i otyłych. Poza określeniem bezpieczeństwa stosowania $A$. muciniphila badano także takie parametry metaboliczne pacjentów, jak: insulinooporność, poziom lipidów we krwi, otyłość trzewna i masa ciała. Obserwowano także wpływ $A$. muciniphila na funkcjonowanie bariery jelitowej (określany na podstawie poziomu LPS w osoczu) oraz na skład mikrobioty jelitowej. W tracie trzymiesięcznego badania pacjenci otrzymywali dzienną doustna dawkę $10^{10}$ żywych bądź pasteryzowanych komórek $A$. muciniphila. W porównaniu z placebo, pasteryzowana $A$. muciniphila poprawiła wrażliwość na insulinę, zmniejszyła insulinemię oraz poziom cholesterolu w osoczu. Pasteryzowana $A$. muciniphila nieznacznie obniżyła także masę ciała oraz masę tkanki tłuszczowej oraz obwód uda. Po trzech miesiącach stosowania $A$. muciniphila zredukowała we krwi poziom istotnych markerów dysfunkcji wątroby oraz stanu zapalnego. Ogólna struktura mikrobioty jelitowej nie została jednak zmieniona [22].

Z przeprowadzaniem badań z udziałem pacjentów chorych na cukrzycę typu 2 wiążą się często dodatkowe komplikacje związane z czynnikami środowiskowymi wpływającymi na interpretację wyników. Nie można zapominać, że wpływ na stan mikrobioty u tych osób mają nie tylko ich choroba, lecz także przyjmowane leki oraz dieta. Wspomniana już wcześniej metformina jest lekiem pierwszego wyboru przepisywanym pacjentom od ponad 60 lat w terapii cukrzycy typu 2 (ze względu na jej bezpieczeństwo i pozytywne oddziaływanie na układ sercowo-naczyniowy). Efekt obniżenia poziomu glukozy we krwi pierwotnie przypisywany był redukcji przez metforminę wątrobowej glukoneogenezy. Niezależnie od tego stwierdzono, że ilość metforminy zakumulowanej w błonie śluzowej przewodu pokarmowego jest o wiele wyższa niż wykrywana w osoczu. Dodatkowo okazało się, że efekt obniżenia poziomu glukozy we krwi, wywołany zastosowaniem niedawno wynalezionych tabletek o przedłużonym uwalnianiu metforminy, mimo mniejszej jej biodostępności w takiej postaci, nie różni się zbytnio od efektu wywołanego taką samą dawką metforminy przyjętą w postaci preparatu o natychmiastowym uwalnianiu. Działanie tego leku jest także silniejsze w przypadku podania go bezpośrednio do jelit niż dożylnie. $Z$ tego względu wydaje się możliwe, że metaboliczne korzyści przypisywane stosowaniu metforminy mogą być skutkiem jej oddziaływania na jelita. Zarówno u człowieka jak i u gryzoni wielokrotnie wykazano, iż lek ten zwiększa poziom GLP-1 we krwi. Wynika to z jego oddziaływania na zależny od glukozy efekt insulinotropowy i glukagonostatyczny oraz z opóźnienia opróżnienia gastrycznego [55]. Niedawne badania in vitro wykazały także, że 24-godzinna ekspozycja na metforminę bezpośrednio stymuluje sekrecję GLP-1 przez komórki L jelita [56]. Najnowsze badania podkreślają także rolę tego leku w modyfikowaniu składu mikrobioty jelitowej, w tym promowanie rozwoju bakterii wytwarzających SCFAs u pacjentów z cukrzycą typu 2. Badanie z podwójnie ślepą próbą prowadzone na pacjentach z cukrzycą typu 2, u których nie stosowano uprzednio leczenia, wykazało, że po czterech miesiącach metformina wywołała zmiany we względnej liczbie więcej niż 80 gatunków bakterii (w porównaniu do grupy przyjmującej placebo). Ponadto, transfer mikrobioty jelitowej ze stolców osób przyjmujących metforminę do pozbawionych mikrobioty jelitowej myszy karmionych HFD poprawił u nich tolerancję glukozy. Dowiedziono tym samym, że zmodyfikowana przez ten lek mikrobiota może także obniżyć poziom glukozy we krwi. Ci sami badacze zaobserwowali także $\mathrm{w}$ badaniach in vitro bezpośredni wzrost liczby $A$. muciniphila spowodowany podawaniem metforminy [57].

\section{A. muciniphila a nieswoiste zapalenie jelita}

Nieswoiste zapalenie jelit (IBD) jest przewlekłą chorobą przewodu pokarmowego, charakteryzującą się nadmierną odpowiedzią immunologiczną na mikrobiotę jelitową. Jest to poważna i wycieńczająca choroba, zwiększająca ryzyko raka jelita grubego i mogąca doprowadzić do zagrażających życiu komplikacji. Wyróżnia się dwie postacie IBD: chorobę Leśniowskiego-Crohna (CD) i wrzodziejące zapalenie jelita grubego (UC). W następstwie spotkania z antygenami, a także z metabolitami mikroorganizmów, które przedostały się przez barierę jelitową, komórki dendrytyczne (i inne komórki prezentujące antygen) inicjują kaskadę sygnałów pro- i przeciwzapalnych. Ich celem jest przyciągnięcie zarówno lokalnych, jak i krążących limfocytów w miejsce wystąpienia stanu zapalnego [58]. Wywołany stanem zapalnym wzrost ilości reaktywnych form tlenu czy azotu 
prowadzi do stresu oksydacyjnego oddziałującego zarówno na komórki gospodarza, jak i na mikrobiotę jelitową [59]. Skutkiem tego jest stan dysbiozy jelitowej polegający na zmniejszeniu bogactwa społeczności bakteryjnej i proliferacji fakultatywnych beztlenowców z rodziny Enterobacteriaceae oraz enteroadhezyjnych szczepów E. coli. Tradycyjna terapia IBD składa się z leków immunosupresyjnych, kortykosteroidów czy przeciwciał anty-TNF- $\alpha$, często podawanych razem $z$ antybiotykami [43].

Liczne badania wykazały zmniejszenie liczebności $A$. muciniphila w mikrobiocie (zarówno fekalnej jak i w próbkach biopsji błony śluzowej jelita) osób z IBD i UC. Spadek ten obserwowany był zarówno w aktywnej chorobie, jak i u pacjentów w remisji [51]. Wyniki niedawno opublikowanego artykułu sugerują, że $A$. muciniphila, a także inne probiotyki nowej generacji ( $F$. prausnitzii), mogą stanowić jeden z elementów terapii IBD [25]. Warto jednak zaznaczyć, że badanie to przeprowadzono w grupie Chińczyków, którzy w porównaniu z Europejczykami (w populacji których $A$. muciniphila jest obecna właściwie u 100\% badanych) charakteryzują się ponaddwukrotnie mniejszym odsetkiem występowania A. muciniphila w populacji - stąd ocenianym w badaniu parametrem była nie tylko liczebność, ale i sama obecność bakterii. Zhang i wsp. [25] w grupie chorych na IBD zaobserwowali mniejszy odsetek osób, u których wykryto obecność A. muciniphila oraz jej mniejszą liczebność. W następnym etapie badania osobom z IBD przeszczepiono oczyszczoną mikrobiotę od zdrowych dawców i okazało się, że zmienia ona zarówno obecność, jak i liczebność $A$. muciniphila u biorcy, upodabniając ją do tej występującej u dawcy. Kolonizacja jelit pacjenta przez A. muciniphila następuje także wtedy, kiedy nie odnotowano obecności tej bakterii u pacjenta przed przeszczepem mikrobioty. Odpowiedź kliniczną zaobserwowano u 53,7\% pacjentów po przeszczepie, a odsetek osób, u których odnotowano występowanie A. muciniphila, zwiększył się. Gdy porównano dwie grupy pacjentów z IBD: tych u których wystąpiła odpowiedź kliniczna z tymi nieodpowiadającymi na terapię, zauważono, że w pierwszej grupie było więcej przypadków występowania A. muciniphila w mikrobiocie [25]. Wcześniej Kump i wsp. [60] wykazali, że w przypadku przeszczepu mikrobiota dawcy bogata $w A$. muciniphila miała większe szanse na wywołanie remisji choroby u pacjenta niż mikrobiota o niższej liczebności tej bakterii. Badania te sugerują, że efekt terapeutyczny przeszczepu mikrobioty u pacjentów z IBD może się wiązać z zasiedlaniem jelit przez A. muciniphila. Zauważono również, że zmianom liczebności A. muciniphila towarzyszyła zmiana liczebności F. prausnitzii [25].

\section{A. muciniphila a schorzenia wątroby}

Choroby wątroby zalicza się do skomplikowanych zaburzeń metabolicznych, a jedną z ich przyczyn jest otyłość bądź wywołane nią zmiany w mikrobiocie jelitowej [61]. Liczne badania z udziałem zarówno zwierząt laboratoryjnych, jak i ludzi potwierdzają istnienie związku między dietą i mikrobiotą a stanem wątroby. Uprzednio pozbawione mikrobioty jelitowej myszy po przeszczepieniu im bakterii jelitowych pochodzących od myszy karmionych HFD (charakteryzujących się wysokim stężeniem glukozy we krwi), były bardziej podatne na rozwinięcie stłuszczenia wątroby oraz insulinooporności niż myszy z grupy kontrolnej, którym przeszczepiano mikrobiotę jelitową od zdrowych dawców [62]. Badania z udziałem ludzi wykazały natomiast znacznie mniejszą liczebność Bacteroidetes u pacjentów cierpiących na niealkoholowe stłuszczenie wątroby niż u osób zdrowych [63]. Pacjenci cierpiący na alkoholowe zapalenie wątroby charakteryzowali się wyraźnym zmniejszeniem liczby A. muciniphila w porównaniu z osobami zdrowymi [64]. Inne badania wskazują także na to, że $A$. muciniphila może mieć znaczenie również w rozwoju stłuszczenia wątroby, zapalenia wątroby oraz hipercholesterolemii [61].

Doustna suplementacja $A$. muciniphila spowodowała u myszy wzrost populacji tej bakterii zdziesiątkowanej przez ekspozycję na etanol. Podaż A. muciniphila może zapobiegać więc alkoholowemu uszkodzeniu tego narządu. Może zapobiec także infiltracji wątroby przez neutrofile (czyli wywołaniu stanu zapalnego) oraz jej stłuszczeniu [27]. W mysim modelu immunologicznego uszkodzenia wątroby doustne podanie $A$. muciniphila obniżyło poziom aminotransferazy alaninowej i aminotransferazy asparaginianowej w osoczu oraz łagodziło uszkodzenie wątroby [57]. Badania wskazują, że dobroczynne działanie A. muciniphila na wątrobę może się wiązać $z$ jej korzystnym oddziaływaniem na barierę jelitową ( $w$ tym na błonę śluzową oraz wytwarzanie białek TJs), która chroni organizm przed nadmierną ekspozycją na etanol [27].

\section{A. muciniphila a zaburzenia neurologiczne}

W ostatnich latach odkryto, iż układ pokarmowy oraz ośrodkowy układ nerwowy połączone są ze sobą siecią komunikacyjną, zwaną osią jelito-mózg. Badania wykazały, że pośredniczy ona w dwukierunkowych interakcjach między mózgiem a jelitami (a konkretniej mikrobiotą jelitową). Głównymi jej elementami są ośrodkowy układ nerwowy, autonomiczny układ nerwowy, jelitowy układ nerwowy, a także oś podwzgórze-przysadka-nadnercza. Komunikacja na osi jelito-mózg zachodzi za pośrednictwem szlaków, które można podzielić na neuronalne, humoralne oraz immunologiczne i umożliwia integrację procesów zachodzących w jelitach (takich jak aktywacja odporności, przepuszczalność jelita, odruch jelitowy czy przekaźnictwo 
enteroendokrynne) z działaniem ośrodków emocjonalnych i poznawczych mózgu. Wiadomo, że mikrobiota jelitowa za pośrednictwem osi jelito-mózg może wpływać na ośrodkowy układ nerwowy. Wiele badań wskazuje na występowanie zaburzeń w składzie mikrobioty jelitowej, a w konsekwencji zaburzeń w komunikacji jelito-mózg w przebiegu niektórych chorób psychiatrycznych i neurologicznych [65].

Serotonina (5-HT, 5-hydroksytryptamina) jest neuroprzekaźnikiem w ośrodkowym układzie nerwowym (OUN) oraz hormonem regulującym liczne procesy w innych tkankach. Jej najlepiej poznane funkcje, związane z OUN, dotyczą kontroli nastroju, snu czy lęków [66]. W OUN, po aktywacji receptora 5-HTR przez serotoninę, jest ona wychwytywana zwrotnie z przestrzeni synaptycznej przez swoiste transportery. Zmiany w funkcjonowaniu tych receptorów i/lub transporterów są wiązane $z$ licznymi schorzeniami neurologicznymi (schizofrenią, nałogami, spektrum zaburzeń autystycznych oraz zaburzeniami: nastroju, lękowymi i hiperkinetycznymi). OUN nie jest jednak głównym miejscem syntezy 5-HT, około 90\% tego hormonu jest wytwarzane przez komórki enterochromafinowe jelita [65]. Wiadomo, że proces ten może być modulowany przez mikrobiotę jelitową i tym samym może pełnić ona kluczową rolę w procesach, w które zaangażowana jest 5-HT [67].

Wykazano, że A. muciniphila może stymulować syntezę 5-HT nie tylko w okrężnicy, ale także w mózgu myszy, co potwierdza zwiększony poziom 5-HT w hipokampie zaobserwowany po pięciotygodniowej podaży $A$. muciniphila. Warto tutaj zaznaczyć, że serotonina jest cząsteczką niezdolną do przenikania przez barierę krewmózg, która oddziela obwodową pulę serotoniny od puli tego hormonu wytwarzanej w mózgu [67].

A. muciniphila, jak każda żywa komórka, jest zdolna do wytwarzania pęcherzyków zewnątrzkomórkowych (EVs, extracellular vesicles), czyli porcji różnorodnych cząstek (np. DNA, lipidów, białek itd.) upakowanych w pęcherzyk z błony komórkowej. Służą one komórce przede wszystkim do komunikowania się z otoczeniem [68]. Wykazano, że EVs wydzielane przez A. muciniphila mogą przenikać przez wewnętrzną warstwę błony śluzowej jelita do krwiobiegu, a następnie przenikać przez barierę krew-mózg [69]. Yaghoubfar i wsp. [67], porównując działanie A. muciniphila i jej EVs, wykazali silniejsze działanie EVs na system serotonergiczny zarówno mózgu jak i jelit. Zaobserwowana w tym badaniu ingerencja $A$. muciniphila i jej EVs w syntezę 5-HT za pośrednictwem osi jelito-mózg może sugerować, że ich suplementacja w postaci probiotyków może być wykorzystana w terapii zaburzeń neurologicznych [67].

Zaburzenia ze spektrum autyzmu, w których często współwystępują także zaparcia, łączone są z dysbiozą jelitową polegającą na zwiększeniu stosunku Firmicutes/ Bacteroidetes oraz dużą liczbą fakultatywnych anaerobów, takich jak bakterie z rodzaju Escherichia czy Shigella oraz grzybów z rodzaju Candida. Sugeruje się, że upośledzenie funkcjonowania bariery jelitowej, a w konsekwencji przenikanie do krwi, a także mózgu, bakterii i/lub ich metabolitów bierze udział w patogenezie zaburzeń ze spektrum autyzmu. W wyniku upośledzenia funkcjonowania bariery jelitowej wzrasta więc poziom niektórych metabolitów oddziałujących na układ neuroendokrynny i neuroimmunologiczny, co wpływa na mózg i rozwój neurologiczny [43].

W ostatnich latach w terapii różnych zaburzeń neurologicznych (w tym lekoopornej epilepsji, zaburzeń ze spektrum autyzmu, choroby Alzheimera i Parkinsona) stosowana była także dieta ketogenna (KD, ketogenic diet), która daje bardzo obiecujące wyniki. Polega ona na ograniczeniu spożycia węglowodanów celem stworzenia stanu ketozy, podczas którego organizm do wytwarzania energii będzie zużywał głównie ciała ketonowe, a nie glukozę. Początkowo zakładano, iż jej działanie wynika z normalizacji nieprawidłowego metabolizmu energetycznego, wiązanego z tymi chorobami. Obecnie uważa się, że i tu mikrobiota jelitowa może odgrywać pewną rolę [43]. Niedawno przeprowadzono badanie porównujące efekt zastosowania KD u myszy o naturalnej mikrobiocie jelitowej z efektem zastosowania KD u myszy traktowanych jednocześnie antybiotykami. Wyniki badania, w którym sprawdzano odporność tych myszy na elektrowstrząsy, wykazały, że do uzyskania przeciwpadaczkowego działania KD niezbędna jest obecność mikrobioty jelitowej [70]. W następstwie stosowania KD zaobserwowano także wzrost populacji bakterii z rodzajów Akkermansia i Parabacteroides, a także zwiększony w hipokampie poziom neuroprzekaźnika hamującego, jakim jest GABA. Dla zaburzeń takich jak epilepsja, stany lękowe czy choroba Alzheimera typowa jest nadmierna pobudliwość neuronalna, wytwarzany zaś przez A. muciniphila GABA jest kluczowym pośrednikiem w redukcji komunikacji między komórkami mózgu. Jest to kolejny przykład pozytywnego wpływu mikrobioty jelitowej i jej metabolitów na organizm gospodarza, a zarazem jedna z przyczyn korzystnego działania KD [43].

Przeszczep mikrobioty jelitowej (FMT, fecal microbiota transplantation) to kolejna opcja terapeutyczna, tym razem opierająca się na mikrobiocie pochodzącej bezpośrednio od zdrowego dawcy bądź standaryzowanej ludzkiej mikrobiocie jelitowej (SHGM, standarized human gut microbiota). SHGM składa się z mieszaniny zawierającej w ponad 99\% komórki bakteryjne, do której stworzenia jako materiału wyjściowego użyto stolców zdrowych dawców, ściśle przebadanych pod kątem infekcji, chorób metabolicznych, gastrologicznych, neurologicznych czy zaburzeń rozwoju układu nerwowego [71]. W badaniu 18 autystycznych dzieci zastosowano terapię polegającą na doustnym bądź doodbytniczym podawaniu 
SHGM (poprzedzoną dwutygodniową terapią antybiotykami oraz przeczyszczeniem jelit $\mathrm{w}$ celu zniszczenia/usunięcia dotychczasowej mikrobioty). W badaniu zastosowano początkowo większą dawkę SHGM, a następie podawano pacjentom mniejszą dawkę SHGM codziennie przez 7-8 tygodni. Terapia spowodowała poprawę zachowania i $80 \%$ zmniejszenie bólu brzucha oraz symptomów ze strony układu pokarmowego. Poprawa utrzymała się po zakończeniu terapii, wspierając tym samym hipotezę, że przynajmniej częściowo za symptomy autyzmu odpowiedzialne są zaburzenia mikrobioty jelitowej [71].

Inna choroba dotykająca układ nerwowy jest choroba Alzheimera (AD, Alzheimer's disease), schorzenie neurodegeneracyjne o globalnym znaczeniu, pozbawione skutecznych metod łagodzenia jego przebiegu. Zespół metaboliczny, w tym otyłość i insulinooporność, stanowi jeden z kluczowych czynników ryzyka rozwoju choroby Alzheimera. Wpływ A. muciniphila na metabolizm glukozy i lipidów oraz na integralność bariery jelitowej został przebadany w mysim modelu choroby Alzheimera. $U$ zwierząt tych przebadano także zmiany zachodzące w mózgu. Powszechnie za główny biomarker choroby Alzheimera uznawany jest amyloid $\beta(A \beta)$. Po podaniu $A$. muciniphila u badanych myszy zauważono redukcję poziomu $A \beta$ w korze mózgowej, skrócenie czasu nauki i polepszone wyniki w teście labiryntu Y, czyli w teście badającym pamięć przestrzenną i krótkotrwałą u myszy [72]. A. muciniphila wpłynęła korzystnie także na tolerancję glukozy, barierę jelitową oraz dyslipidemię. Na tej podstawie badacze stwierdzili, że $A$. muciniphila może opóźnić wystąpienie patologicznych zmian w mózgu myszy i łagodzić upośledzenie pamięci oraz uczenia przestrzennego [11, 73].

Mimo iż w większości badań wysoki poziom $A$. muciniphila jest pozytywnym zjawiskiem, korelującym z prawidłowym funkcjonowaniem organizmu, to istnieja także przypadki, w których duża liczebność $A$. muciniphila w kale pacjentów nie jest kojarzona ze zdrowiem. Wiele prac analizujących chorobę Parkinsona oraz stwardnienie rozsiane (MS, multiple sclerosis) wskazuje na różnice między liczebnością bakterii poszczególnych gatunków (w tym A. muciniphila) w przewodach pokarmowych osób zdrowych i osób chorych. U pacjentów z MS zaobserwowano w ich kale zwiększoną liczebność A. muciniphila. Wykazano także, przeszczepiwszy mikrobiotę chorych pacjentów myszom stanowiących model MS, że obecność mikrobioty pacjentów chorych pogarsza stan myszy (zwiększa progresję choroby). Jednak badanie to nie wykazało, żeby po przeszczepie $w$ organizmie myszy zachodziły jakiekolwiek dalsze zmiany w liczebności $A$. muciniphila. Na tym etapie

\begin{tabular}{|c|c|c|c|c|c|}
\hline & Otylosé & $\begin{array}{l}\text { Nieleczona } \\
\text { cukrzyca typu } 2\end{array}$ & $\begin{array}{l}\text { Leczona } \\
\text { cukrayca typu } 2\end{array}$ & $\begin{array}{l}\text { Bypass } \\
\text { gastrycany }\end{array}$ & $\begin{array}{l}\text { Choroba Parkinsona } \\
\text { istwardnienie } \\
\text { rozsiane }\end{array}$ \\
\hline Liczebność $A$. muciniphila & yy & yy & $\pi(\pi)$ & ที丶 & 7 \\
\hline $\begin{array}{l}\text { Glówne czynniki } \\
\text { komplikujace } \\
\text { interpretację } \\
\text { wyników badań }\end{array}$ & \multicolumn{2}{|c|}{$\begin{array}{l}\text { Niska podaż błonnika w diecie } \\
\text { Dieta wysokotluszczowa } \\
\text { i wysokowęglowodanowa } \\
\text { Zmniejszona grubość błony } \\
\text { śluzowej/wytwarzanie śluzu }\end{array}$} & $\begin{array}{l}\text { Metformina jako źródło } \\
\text { energii dla } \\
\text { A. muciniphila } \\
\text { Wzrost liczby komórek } \\
\text { kubkowych wywołany } \\
\text { metformina } \\
\text { Inne zmiany w } \\
\text { mikrobiocie wywołane } \\
\text { metformina }\end{array}$ & $\begin{array}{l}\text { Duży przepływ } \\
\text { niestrawionych } \\
\text { składników } \\
\text { pokarmowych } \\
\text { stanowiących } \\
\text { źródło energii dla } \\
\text { A. muciniphila }\end{array}$ & $\begin{array}{l}\text { Wydhużony czas } \\
\text { transportu pokarmu } \\
\text { przez jelita oraz } \\
\text { zaparcia } \\
\text { Leki } \\
\text { Okresy zmniejszonej } \\
\text { podaży kalorycznej } \\
\text { oraz inne zmiany w } \\
\text { przyjmowaniu } \\
\text { pokarmów }\end{array}$ \\
\hline $\begin{array}{l}\text { Udowodnienie } \\
\text { bezpośrednich } \\
\text { powiązań między } \\
\text { obecnością } \\
\text { A. muciniphila } \\
\text { a chorobą }\end{array}$ & $\sqrt{ }$ & $\sqrt{ }$ & $\sqrt{7}$ & $\sqrt{ }$ & $x$ \\
\hline
\end{tabular}

Rycina 8. Zależności między A. muciniphila a różnymi stanami chorobowymi - znane fakty i wątpliwości w ich interpretacji. Kierunek strzałki obrazuje przyrost lub spadek liczebności $A$. muciniphila, a liczba strzałek wskazuje na intensywność zmiany. Według [1], licencja Creative Commons Attribution Non Commercial (CC BY-NC 4.0) 
badań nie można więc stwierdzić, by to $A$. muciniphila była odpowiedzialna za wystąpienie choroby. Według Cani [1] badania z udziałem ludzi są bardziej skomplikowane, ponieważ zmiany w mikrobiocie pacjentów mogą wiązać się $z$ różnymi czynnikami wynikającymi z warunków i stylu życia - ze zmianami w przyjmowaniu pokarmów (np. okresami o zmniejszonej podaży kalorycznej), dolegliwościami (np. zaparciami) czy przyjmowanymi lekami i/lub suplementami. Pacjenci zaś nie o wszystkich tych czynnikach informują badaczy. Jest to bardzo ważny aspekt, o którym należy pamiętać, kiedy analizuje się dane wskazujące na korelacje między liczebnością bakterii a określonym stanem organizmu. Warto także zaznaczyć, iż być może w patogenezie opisanych stanów chorobowych ważniejsze od liczebności samej $A$. muciniphila są zaburzenia proporcji między różnymi gatunkami mikrobioty. Zależności między A. muciniphila a wspomnianymi dotychczas stanami chorobowymi podsumowano na ryc. 8 .

\section{A. muciniphila a astma}

Astma charakteryzuje się nawracającą i odwracalną niedrożnością dróg oddechowych, wywołaną występującym w nich stanem zapalnym. Różne mechanizmy molekularne mogą prowadzić do podobnych objawów klinicznych, stąd też wyróżnia się różne typy astmy różniące się mechanizmami patofizjologicznymi. Aby prawidłowo zrozumieć złożone interakcje między wrodzoną i nabytą odpowiedzią immunologiczną w astmie, pod uwagę należy wziąć takie dodatkowe czynniki jak: stan mikrobioty jelitowej, dieta oraz aktywność metaboliczna pacjenta. Podejście takie umożliwia znalezienie terapii wymierzonej precyzyjnie przeciwko zaburzonym mechanizmom, odpowiedniej dla danego pacjenta. Jedną ze zmiennych wyróżniających poszczególne typy astmy jest otyłość. Otyli astmatycy częściej stają się oporni na stosowane w leczeniu astmy kortykosteroidy, co zwiększa u nich ryzyko hospitalizacji i cięższego przebiegu choroby. Badacze postanowili scharakteryzować zmiany zachodzące w układzie immunologicznym oraz mikrobiocie jelitowej $u$ otyłych osób z astmą, aby sprawdzić, czy zmiany te są związane z astmą, otyłością czy obiema tymi przypadłościami. W badaniu udział wzięli otyli astmatycy, astmatycy o prawidłowej masie ciała, osoby otyłe niechorujące na astmę oraz osoby zdrowe o prawidłowej masie ciała. Okazało się, że otyłość koreluje z podniesionym poziomem markerów stanu zapalnego, który dodatkowo wzrastał w przypadku wystąpienia astmy. $U$ obu grup astmatyków zaobserwowano także negatywną korelację między liczbą A. muciniphila a poziomem krążącego białka ostrej fazy (jednego z markerów stanu zapalnego). Dane te sugerują, że obniżony poziom $A$. muciniphila może być związany ze zwiększonym ryzykiem cięższego przebiegu choroby.
Również zmiany w mikrobiocie wywołane astmą lub otyłością charakteryzował efekt addytywny w przypadku wystąpienia obu tych schorzeń jednocześnie. Ostrość przebiegu astmy korelowała negatywnie $z$ poziomem $A$. muciniphila w stolcach pacjentów. Zbadano także związki przyczynowoskutkowe między zmianami zachodzącymi w mikrobiocie a przebiegiem choroby. Wykazano, że doustna podaż $A$. muciniphila mysim modelom astmy znacząco zmniejszyła nadreaktywność na alergeny oraz stan zapalny w drogach oddechowych [74].

\section{Zastosowanie A. muciniphila w terapiach przeciwnowo- tworowych}

Związki A. muciniphila z układem odpornościowym wydają się ważne nie tylko $w$ chorobach metabolicznych, ale także w terapiach przeciwnowotworowych. Wiadomo już powszechnie, że terapie te mogą w pewnym stopniu opierać się na funkcjonowaniu mikrobioty jelitowej ( $w$ tym $A$. muciniphila), gdyż wpływa ona na wynik terapii opartych na działaniu układu immunologicznego, takich jak np. terapia anty-PD-1 [1].

Receptor śmierci programowanej 1 (PD-1, programmed death receptor 1) to receptor występujący na powierzchni komórek limfocytów T, B oraz komórkach linii mieloidalnej, pełniący funkcję regulatora układu odpornościowego. Może promować autotolerancję przez hamowanie odpowiedzi zapalnej limfocytów T. PD-1 stanowi tzw. punkt kontrolny (check point) o podwójnej funkcji: indukuje apoptozę w komórkach limfocytów $\mathrm{T}$ antygenoswoistych oraz redukuje apoptozę limfocytów $T$ regulatorowych, które przez hamowanie aktywności układu odpornościowego zapobiegają chorobom autoimmunologicznym. To drugie działanie może jednak prowadzić także do zahamowania odpowiedzi układu odpornościowego na komórki nowotworowe [75].

Początkowe obserwacje wykazały, że pacjenci odpowiadający pozytywnie na terapię anty-PD-1 charakteryzowali się zwiększoną liczbą $A$. muciniphila w jelitach, w porównaniu z pacjentami nieodpowiadającymi na terapię. Jednak jest to jedynie korelacja, dlatego w kolejnych etapach badań przeszczepiono dwóm grupom myszy mikrobiotę odpowiednio od pacjentów odpowiadających lub nieodpowiadających na terapię. Użyte $w$ doświadczeniu myszy były uprzednio pozbawione własnej mikrobioty. Wyniki tego eksperymentu były spójne $z$ obserwacjami dotyczącymi pacjentów - zmniejszona odpowiedź na terapię u myszy o ubogiej w $A$. muciniphila mikrobiocie. Doustne podanie $A$. muciniphila myszom, które wcześniej otrzymały mikrobiotę od pacjentów nieodpowiadających na terapię (z mikrobiotą ubogą w A. muciniphila) przywróciła u nich skuteczność stosowanej terapii. Wskazuje to na kluczową rolę $A$. muciniphila $w$ regulacji mechanizmów 
immunologicznych [76]. Pomimo istotności tych odkryć nie można nadal wykluczyć, że uzyskane efekty są wynikiem interakcji między poszczególnymi gatunkami mikrobioty, a nie wynikiem działania samej $A$. muciniphila. Wymaga to dalszych, pogłębionych badań, w tym tych z udziałem ludzi.

W innym badaniu relacje między mikrobiotą a efektywnością terapii zostały przebadane w grupie 249 pacjentów z nowotworami płuc, nerek i pęcherza, u których stosowano terapie anty PD-1. Pacjenci, którzy przyjmowali antybiotyki przed terapią i po niej, wykazywali słabszą odpowiedź na terapię i krótszy czas przeżycia niż pacjenci, którzy nie otrzymali antybiotyków. W jelitach pacjentów odpowiadających pozytywnie na terapię obserwowano zwiększoną liczebność $A$. muciniphila [11].

\section{Podsumowanie}

Dzięki rozwojowi antybiotykoterapii czy powszechności szczepionek możliwe stało się opanowanie bądź całkowite wyeliminowanie wielu zakaźnych chorób bakteryjnych. Obecnie w krajach kultury zachodniej większe zagrożenie stanowią złożone zaburzenia metaboliczne oraz ich powikłania. Choroby sercowo-naczyniowe, cukrzyca typu 2, zespół metaboliczny, nowotwory nie tylko znacząco pogarszają jakość życia, ale mogą prowadzić także do śmierci pacjenta. Za rozwój większości tego typu zaburzeń jest odpowiedzialnych nie jeden, a wiele czynników o różnym charakterze ( $w$ tym zarówno czynniki środowiskowe, jak i predyspozycje genetyczne). Są to także schorzenia dotykające nierzadko różnych narządów czy układów. $Z$ tych powodów nie jest łatwo opracować preparat, który skutecznie walczyłby z chorobą. Stąd też, poza leczeniem farmakologicznym, w przebiegu licznych chorób ważny jest zdrowy tryb życia, uwzględniający przede wszystkim odpowiednią do zapotrzebowania pacjenta dietę oraz ćwiczenia fizyczne, ale także odpowiednią ilość snu czy wypoczynku.

Choć zbawienny wpływ zdrowego trybu życia na profilaktykę i leczenie wielu chorób wydaje się oczywisty, to mechanizmy odpowiadające za to działanie nie są dokładnie poznane. Jednym ze sposobów ich odkrycia jest porównywanie wielu parametrów między osobami zdrowymi a cierpiącymi na różne schorzenia. Funkcjonowanie mikrobioty jelitowej było jednym $z$ takich parametrów i okazało się, że wyraźnie koreluje ze stanem zdrowia gospodarza. To z kolei spowodowało ogromne zainteresowanie relacjami przyczynowo-skutkowymi między różnymi gatunkami mikrobioty a patogenezą chorób. Poszukując, wśród gatunków zasiedlających układ pokarmowy człowieka, bakteryjnych kandydatów na probiotyki nowej generacji, badacze trafili na $A$. muciniphila.
A. muciniphila jest wyjątkowo obiecującym kandydatem na probiotyk nowej generacji, gdyż jej działanie na organizm człowieka nie wiąże się z jednym tylko efektem, ale wywołuje wiele zmian, dotykających zarówno bezpośrednio, jak i pośrednio (przez interakcje z innymi gatunkami mikrobioty) organizmu gospodarza. Przez oddziaływanie z innymi bakteriami $A$. muciniphila przyczynia się do wytwarzania przez nie wielu korzystnych metabolitów (w tym SCFAs) oraz zapobiega nadmiernemu stężeniu tych szkodliwych (np. siarkowodoru). Na zasadzie konkurencji chroni organizm gospodarza przed inwazją bakterii patogennych. Jednocześnie zarówno ona sama, jak i jej białko błonowe Amuc_1100 mogą oddziaływać z układem immunologicznym gospodarza, ograniczając przede wszystkim występowanie stanu zapalnego, odpowiedzialnego za patogenezę wielu zaburzeń metabolicznych. Wpływa także korzystnie na funkcjonowanie bariery jelitowej, uniemożliwiając translokację bakterii patogennych w głąb tkanek. Stymuluje także wydzielanie AMPs i pobudza komórki układu odpornościowego do sprawnego zwalczania bakterii patogennych. Dzięki wytwarzaniu SCFAs wpływa także na regulację metabolizmu energetycznego.

Liczne badania na zwierzętach laboratoryjnych oraz mniej liczne z udziałem ludzi zdają się potwierdzać, iż suplementacja $A$. muciniphila poprawia stan zdrowia osób cierpiących na zaburzenia metabolizmu energetycznego, zaburzenia neurologiczne czy związane $z$ funkcjonowaniem układu odpornościowego, takie jak IBD i astma, oraz wpływa pozytywnie na odpowiedź pacjentów na terapie przeciwnowotworowe oparte o działanie tego układu.

Dotychczasowe dane słusznie sugerują, że $A$. muciniphila może być obiecującym kandydatem na probiotyk nowej generacji. Warto jednak pamiętać, iż obecnie nie jest łatwo stwierdzić, które efekty podaży $A$. muciniphila zaobserwowane $w$ badaniach są wynikiem działania jej samej, a które są bardziej związane z interakcjami między bakteriami w obrębie mikrobioty. Pytanie to nasuwa kolejne, tym razem o bezpieczeństwo takiej ingerencji w skład mikrobioty. Dotychczasowe badania zdają się potwierdzać skuteczność oraz bezpieczeństwo stosowania A. muciniphila zarówno w postaci żywych, jak i pasteryzowanych bakterii czy też samego białka Amuc_1100. Niewątpliwie jednak przed dopuszczeniem A. muciniphila do powszechnego stosowania konieczne są dalsze badania z udziałem ludzi, a także wnikliwa ocena bezpieczeństwa jej stosowania.

\section{Wykaz skrótów}

5-HT - serotonina (5-hydroxytryptamine); $\boldsymbol{A} \boldsymbol{\beta}$ - amyloid $\beta ;$ AD - choroba Alzheimera (Alzheimer's disease); ALT aminotransferaza alaninowa (alanine aminotransferase); 
AMPs - peptydy antydrobnoustrojowe (antimicrobial peptides); AST - aminotransferaza asparaginianowa (aspartate aminotransferase); BCFAs - rozgałęzione kwasy tłuszczowe (branched chain fatty acids); CCL20 chemokine 20 należąca do grupy chemokin CC (chemokine C-C motif ligand 20); CCR6 - receptor 6 dla chemokin z grupy CC (chemokine receptor 6); CD - choroba Leśniowskiego-Crohna (Crohn's disease); DAMPs wzorce molekularne związane z uszkodzeniem (damage associated molecular patterns); ERK - kinaza regulowana przez zewnątrzkomórkowe sygnały (extracellular signalregulated kinase); EVs - pęcherzyki zewnątrzkomórkowe (extracellular vesicles); FFAR - receptor wolnych kwasów tłuszczowych (free fatty acid receptor); FISH fluorescencyjna hybrydyzacja in situ (fluorescent in situ hybridization); GABA - kwas gamma-aminomasłowy (gamma-aminobutyric acid); GALT - tkanka limfatyczna związana z układem pokarmowym (gut associated lymphoid tissue); GLP1 - glukagonopodobny peptyd 1 (glucagonlike peptide-1); GPR - receptor związany z białkiem G (G protein-coupled receptor); HDAC - deacetylaza histonów (histone deacetylase); HFD - dieta wysokotłuszczowa (high fat diet); IBD - nieswoiste zapalenie jelit (inflammatory bowel disease); IFN- $\mathbf{\gamma}$ - interferon gamma; Ig - immunoglobulina; IL - interleukina; ILCs - limfocyty wrodzone (innate lymfoid cells); ILFs - grudki limfatyczne izolowane (isolated lymphoid follicles); IP-GTT - dootrzewnowy test tolerancji glukozy (intraperitoneal glucose tolerance test); IP-ITT dootrzewnowy test tolerancji insuliny (intraperitoneal insulin tolerance test); KD - dieta ketogenna (ketogenic diet); LDL lipoproteina o niskiej gęstości (low-density lipoprotein); LPS - lipopolisacharyd; MALT - tkanka limfatyczna związana z błonami śluzowymi (mucosa associated lymphoid tissue); MAPK - kinaza białkowa aktywowana mitogenami (mitogen-activated protein kinase); MS - stwardnienie rozsiane (multiple sclerosis); NIACR1 - receptor niacyny 1 (niacin receptor 1); NK - naturalne komórki cytotoksyczne (natural killer); NLRs - receptory NOD-podobne (NODlike receptors); OUN - ośrodkowy układ nerwowy; PAMPs - wzorce molekularne związane z patogenami (pathogen associated molecular patterns); PD-1 - receptor śmierci programowanej 1 (programmed death receptor 1); PD-L - ligand receptora śmierci programowanej (programmed death-ligand); PRRs - receptory rozpoznające wzorce molekularne (pattern recognition receptors); PYY - peptyd YY (peptide YY); qPCR - ilościowa reakcja łańcuchowa polimerazy (quantitative polymerase chain reaction); SCFAs - krótkołańcuchowe kwasy tłuszczowe (short-chain fatty acids); SEM - skaningowy mikroskop elektronowy (scanning electron microscope); SHGM - standaryzowana ludzka mikrobiota jelitowa (standardized human gut microbiota); TEM - transmisyjny mikroskop elektronowy (transmission electron microscope); TJs - połączenia ścisłe (tight junctions); TLRs - receptory Toll-podobne (Toll-like receptors); TMAO - N-tlenek trimetyloaminy (trimethylamineN-oxide); TNF - czynnik martwicy nowotworu (tumor necrosis factor); Treg - limfocyty $T$ regulatorowe; TSA trichostatyna A (trichostatin A); UC - wrzodziejące zapalenie jelita grubego (ulcerative colitis).

\section{Podziękowania}

Autorki bardzo dziękują dr Katarzynie Roeske za wnikliwe przeczytanie manuskryptu i wszystkie krytyczne uwagi, które pozwoliły ulepszyć tę pracę.

\section{Konflikt interesów}

Autorki deklarują brak potencjalnych konfliktów interesów.

\section{Piśmiennictwo}

[1] Cani P.D.: Human gut microbiome: Hopes, threats and promises. Gut, 2018; 67: 1716-1725

[2] Berg G., Rybakova D., Fischer D., Cernava T., Vergès M.C., Charles T., Chen X., Cocolin L., Eversole K., Corral G.H. i wsp.: Microbiome definition re-visited: Old concepts and new challenges. Microbiome, 2020; 8: 103

[3] Sender R., Fuchs S., Milo R.: Revised estimates for the number of human and bacteria cells in the body. PLoS Biol, 2016; 14: e1002533

[4] Dominguez-Bello M.G., Godoy-Vitorino F., Knight R., Blaser M.J.: Role of the microbiome in human development. Gut, 2019; 68: 1108-1114

[5] Gomez de Agüero M., Ganal-Vonarburg S.C., Fuhrer T., Rupp S., Uchimura Y., Li H., Steinert A., Heikenwalder M., Hapfelmeier S., Sauer U. i wsp.: The maternal microbiota drives early postnatal innate immune development. Science, 2016; 351: 1296-1302

[6] Koren O., Goodrich J.K., Cullender T.C., Spor A, Laitinen K., Bäckhed H.K., Gonzalez A., Werner J.J., Angenent L.T., Knight R. i wsp.: Host remodeling of the gut microbiome and metabolic changes during pregnancy. Cell, 2012; 150: 470-480

[7] Arpaia N., Campbell C., Fan X., Dikiy S., van der Veeken J., deRoos P., Liu H., Cross J.R., Pfeffer K., Coffer P.J., Rudensky A.Y.: Metabolites produced by commensal bacteria promote peripheral regulatory T-cell generation. Nature, 2013; 504: 451-455

[8] David L.A., Maurice C.F., Carmody R.N., Gootenberg D.B., Button J.E., Wolfe B.E., Ling A.V., Devlin A.S., Varma Y., Fischbach M.A. i wsp.: Diet rapidly and reproducibly alters the human gut microbiome. Nature, 2014; 505: 559-563 
[9] Chang C.J., Lin T.L., Tsai Y.L., Wu T.R., Lai W.F., Lu C.C., Lai H.C.: Next generation probiotics in disease amelioration. J. Food Drug Anal., 2019; 27: 615-622

[10] Martín R., Langella P.: Emerging health concepts in the probiotics field: Streamlining the definitions. Front. Microbiol., 2019; 10: 1047

[11] Naito Y., Uchiyama K., Takagi T.: A next-generation beneficial microbe: Akkermansia muciniphila. J. Clin. Biochem. Nutr., 2018; 63 : 33-35

[12] Zhang T., Li Q., Cheng L., Buch H., Zhang F.: Akkermansia muciniphila is a promising probiotic. Microb. Biotechnol., 2019; 12:1109-1125

[13] Gupta R.S., Bhandari V., Naushad H.S.: Molecular signatures for the PVC clade (Planctomycetes, Verrucomicrobia, Chlamydiae, and Lentisphaerae) of bacteria provide insights into their evolutionary relationships. Front. Microbiol., 2012; 3: 327

[14] Derrien M., van Passel M.W., van de Bovenkamp J.H., Schipper R.G., de Vos W.M., Dekker J.: Mucin-bacterial interactions in the human oral cavity and digestive tract. Gut Microbes, 2010; 1 : 254-268

[15] Derrien M., Vaughan E.E., Plugge C.M., de Vos W.M.: Akkermansia muciniphila gen. nov., sp. nov., a human intestinal mucindegrading bacterium. Int. J. Syst. Evol. Microbiol., 2004; 54: 14691476

[16] NCBI Taxonomy Browser. https://www.ncbi.nlm.nih.gov/Taxonomy/Browser/wwwtax.cgi? mode $=$ Undef\& $i d=74201 \& \mid v l=6 \& l i n=f \&$ keep $=1$ \&srchmode=1\&unlock (25.11.19)

[17] Geerlings S.Y., Kostopoulos I., de Vos W.M., Belzer C.: Akkermansia muciniphila in the human gastrointestinal tract: When, where, and how? Microorganisms, 2018; 6: 75

[18] Ottman N., Geerlings S.Y., Aalvink S., de Vos W.M., Belzer C.: Action and function of Akkermansia muciniphila in microbiome ecology, health and disease. Best Pract. Res. Clin. Gastroenterol., 2017; 31: 637-642

[19] Ottman N., Davids M., Suarez-Diez M., Boeren S., Schaap P.J., Martins Dos Santos V.A., Smidt H., Belzer C., de Vos W.M.: Genome-scale model and omics analysis of metabolic capacities of Akkermansia muciniphila reveal a preferential mucin-degrading lifestyle. Appl. Environ. Microbiol., 2017; 83: e01014-17

[20] Collado M.C., Derrien M., Isolauri E., de Vos W.M., Salminen S.: Intestinal integrity and Akkermansia muciniphila, a mucin-degrading member of the intestinal microbiota present in infants, adults, and the elderly. Appl. Environ. Microbiol., 2007; 73: 7767-7770

[21] Cozzolino A., Vergalito F., Tremonte P., lorizzo M., Lombardi S. J., Sorrentino E., Luongo D., Coppola R., Di Marco R., Succi M.: Preliminary evaluation of the safety and probiotic potential of $A$ kkermansia muciniphila DSM 22959 in comparison with Lactobacillus rhamnosus GG. Microorganisms, 2020; 8: 189

[22] Depommier C., Everard A., Druart C., Plovier H., Van Hul M., Vieira-Silva S., Falony G., Raes J., Maiter D., Delzenne N.M. i wsp.: Supplementation with Akkermansia muciniphila in overweight and obese human volunteers: A proof-of-concept exploratory study Nat. Med., 2019; 25: 1096-1103

[23] Johansson M.E., Larsson J.M., Hansson G.C.: The two mucus layers of colon are organized by the MUC2 mucin, whereas the outer layer is a legislator of host-microbial interactions. Proc. Natl. Acad. Sci. USA, 2011; 108: 4659-4665

[24] Lopez-Siles M., Enrich-Capó N., Aldeguer X., Sabat-Mir M., Duncan S.H., Garcia-Gil L.J., Martinez-Medina M.: Alterations in the abundance and co-occurrence of Akkermansia muciniphila and Faecalibacterium prausnitzii in the colonic mucosa of inflammatory bowel disease subjects. Front. Cell. Infect. Microbiol., 2018; 8: 281

[25] Zhang T., Li P. Wu X., Lu G., Marcella C., Ji X., Ji G., Zhang F.: Alterations of Akkermansia muciniphila in the inflammatory bowel disease patients with washed microbiota transplantation. Appl. Microbiol. Biotechnol., 2020; 104: 10203-10215

[26] Nava G.M., Carbonero F., Croix J.A., Greenberg E., Gaskins H.R.: Abundance and diversity of mucosa-associated hydrogenotrophic microbes in the healthy human colon. ISME J., 2012; 6: 57-70

[27] Grander C., Adolph T.E., Wieser V., Low, P., Wrzosek L., Gyongyosi B., Ward D.V., Grabherr F., Gerner R.R., Pfister A. i wsp.: Recovery of ethanol-induced Akkermansia muciniphila depletion ameliorates alcoholic liver disease. Gut, 2018; 67: 891-901

[28] Hänninen A., Toivonen R., Pöysti S., Belzer C., Plovier H., Ouwerkerk J.P., Emani R., Cani P.D., De Vos W.M.: Akkermansia muciniphila induces gut microbiota remodelling and controls islet autoimmunity in NOD mice. Gut, 2018; 67: 1445-1453

[29] Viggiano D., Ianiro G., Vanella G., Bibbò S., Bruno G., Simeone G., Mele G.: Gut barrier in health and disease: Focus on childhood. Eur. Rev. Med. Pharmacol. Sci., 2015; 19: 1077-1085

[30] Hamada H., Hiroi T., Nishiyama Y., Takahashi H., Masunaga Y., Hachimura S., Kaminogawa S., Takahashi-Iwanaga H., Iwanaga T., Kiyono H. i wsp.: Identification of multiple isolated lymphoid follicles on the antimesenteric wall of the mouse small intestine. J. Immunol., 2002; 168: 57-64

[31] Jung C., Hugot J.P., Barreau F.: Peyer's patches: The immune sensors of the intestine. Int. J. Inflam., 2010; 2010: 823710

[32] Gomes A.C., Hoffmann C., Mota J.F.: The human gut microbiota: Metabolism and perspective in obesity. Gut Microbes, 2018; 9: 308-325

[33] UniProtKB - P51684 (CCR6_HUMAN). https://www.uniprot.org/ uniprot/P51684 (19.03.2020)

[34] Lin Y.L., Ip P.P., Liao F.: CCR6 deficiency impairs IgA production and dysregulates antimicrobial peptide production, altering the intestinal flora. Front. Immunol., 2017; 8: 805

[35] Mazzurana L., Rao A., Van Acker A., Mjösberg J.: The roles for innate lymphoid cells in the human immune system. Semin. Immunopathol., 2018; 40: 407-419

[36] UniProtKB - Q6UW15 (REG3G_HUMAN). https://www.uniprot. org/uniprot/Q6UW15 (19.03.2020) 
[37] Everard A., Belzer C., Geurts L., Ouwerkerk J.P., Druart C., Bindels L.B., Guiot Y., Derrien M., Muccioli G.G., Delzenne N.M. i wsp.: Cross-talk between Akkermansia muciniphila and intestinal epithelium controls diet-induced obesity. Proc. Natl. Acad. Sci. USA, 2013; 110: 9066-9071

[38] Pourahmad J., Salimi A.: Isolated human peripheral blood mononuclear cell (PBMC), a cost effective tool for predicting immunosuppressive effects of drugs and xenobiotics. Iran. J. Pharm. Res., 2015; 14: 979

[39] Ottman N., Reunanen J., Meijerink M., Pietilä T.E., Kainulainen V., Klievink J., Huuskonen L., Aalvink S., Skurnik M., Boeren S. i wsp.: Pili-like proteins of Akkermansia muciniphila modulate host immune responses and gut barrier function. PLoS One, 2017; 12: e0173004

[40] Hiippala K., Jouhten H., Ronkainen A., Hartikainen A., Kainulainen V., Jalanka J., Satokari R.: The potential of gut commensals in reinforcing intestinal barrier function and alleviating inflammation. Nutrients, 2018; 10: 988

[41] Reunanen J., Kainulainen V., Huuskonen L., Ottman N., Belzer C., Huhtinen H., de Vos W.M., Satokari R.: Akkermansia muciniphila adheres to enterocytes and strengthens the integrity of the epithelial cell layer. Appl. Environ. Microbiol., 2015; 81: 36553662

[42] Delgado S., Sánchez B., Margolles A., Ruas-Madiedo P., Ruiz L.: Molecules produced by probiotics and intestinal microorganisms with immunomodulatory activity. Nutrients, 2020; 12: 391

[43] Hills R.D.Jr., Pontefract B.A., Mishcon H.R., Black C.A., Sutton S.C., Theberge C.R.: Gut microbiome: Profound implications for diet and disease. Nutrients, 2019; 11: 1613

[44] Kimura I., Inoue D., Hirano K., Tsujimoto G.: The SCFA receptor GPR43 and energy metabolism. Front. Endocrinol., 2014; 5: 85

[45] Andersen A., Lund A., Knop F.K., Vilsbøll T.: Glucagon-like peptide 1 in health and disease. Nat. Rev. Endocrinol., 2018; 14: 390-403

[46] Vásquez-Garibay E., Larrosa-Haro A., Guzmán-Mercado E., Muñoz-Esparza N., García-Arellano S., Muñoz-Valle F., Romero-Velarde E.: Appetite-regulating hormones and anthropometric indicators of infants according to the type of feeding. Food Sci. Nutr., 2020; 8: 993-1000

[47] Chang P.V., Hao L., Offermanns S., Medzhitov R.: The microbial metabolite butyrate regulates intestinal macrophage function via histone deacetylase inhibition. Proc. Natl. Acad. Sci. USA, 2014; 111: $2247-2252$

[48] Liu H., Wang J., He T., Becker S., Zhang G., Li D., Ma X.: Butyrate: A double-edged sword for health? Adv. Nutr., 2018; 9: 2129

[49] Eckschlager T., Plch J., Stiborova M., Hrabeta J.: Histone deacetylase inhibitors as anticancer drugs. Int. J. Mol. Sci., 2017; 18: 1414

[50] Piekarzewska M., Zajenkowska-Kozłowska A.: Stan zdrowia ludności. W: Stan zdrowia ludności Polski w 2014 r., red.: M.
Piekarzewska, A. Zajenkowska-Kozłowska. Główny Urząd Statystyczny, Warszawa, 2016, 76

[51] Macchione I.G., Lopetuso L.R., Ianiro G., Napoli M., Gibiino G., Rizzatti G., Petito V., Gasbarrini A., Scaldaferri F.: Akkermansia muciniphila: Key player in metabolic and gastrointestinal disorders. Eur. Rev. Med. Pharmacol. Sci., 2019; 23: 8075-8083

[52] Jayachandran M., Chung S.S., Xu B.: A critical review of the relationship between dietary components, the gut microbe Akkermansia muciniphila, and human health. Crit. Rev. Food Sci. Nutr., 2020; 60: 2265-2276

[53] Ley R.E., Turnbaugh P.J., Klein S., Gordon J.I.: Microbial ecology: Human gut microbes associated with obesity. Nature, 2006; 444: 1022-1023

[54] Shin J., Noh J.R., Chang D.H., Kim Y.H., Kim M.H., Lee E.S., Cho S., Ku B.J., Rhee M.S., Kim B.C. i wsp.: Elucidation of Akkermansia muciniphila probiotic traits driven by mucin depletion. Front. Microbiol., 2019; 10: 1137

[55] Pascale A., Marchesi N., Govoni S., Coppola A., Gazzaruso C.: The role of gut microbiota in obesity, diabetes mellitus, and effect of metformin: New insights into old diseases. Curr. Opin. Pharmacol., 2019; 49: 1-5

[56] Kim M.H., Jee J.H., Park S., Lee M.S., Kim K.W., Lee M.K.: Metformin enhances glucagon-like peptide 1 via cooperation between insulin and Wnt signaling. J. Endocrinol., 2014; 220: 117-128

[57] Wu H., Esteve E., Tremaroli V., Khan M.T., Caesar R., Mannerås-Holm L., Ståhlman M., Olsson L.M., Serino M., Planas-Fèlix M. i wsp.: Metformin alters the gut microbiome of individuals with treatment-naive type 2 diabetes, contributing to the therapeutic effects of the drug. Nat. Med., 2017; 23: 850-858

[58] Ramos G.P., Papadakis K.A.: Mechanisms of disease: Inflammatory bowel diseases. Mayo Clin. Proc., 2019; 94: 155-165

[59] Hall A.B., Yassour M., Sauk J., Garner A., Jiang X., Arthur T., Lagoudas G.K., Vatanen T., Fornelos N., Wilson R. i wsp.: A novel Ruminococcus gnavus clade enriched in inflammatory bowel disease patients. Genome Med., 2017; 9: 103

[60] Kump P., Wurm P., Gröchenig H.P., Wenzl H., Petritsch W., Halwachs B., Wagner M., Stadlbauer V., Eherer A., Hoffmann K.M. i wsp.: The taxonomic composition of the donor intestinal microbiota is a major factor influencing the efficacy of faecal microbiota transplantation in therapy refractory ulcerative colitis. Aliment. Pharmacol. Ther., 2018; 47: 67-77

[61] Xu Y., Wang N., Tan H.Y., Li S., Zhang C., Feng Y.: Function of Akkermansia muciniphila in obesity: Interactions with lipid metabolism, immune response and gut systems. Front. Microbiol., 2020; 11: 219

[62] Aron-Wisnewsky J., Gaborit B., Dutour A., Clement K.: Gut microbiota and non-alcoholic fatty liver disease: New insights. Clin. Microbiol. Infect., 2013; 19: 338-348

[63] Fukui H.: Gut microbiota and host reaction in liver diseases. Microorganisms, 2015; 3: 759-791 
[64] Van Best N., Jansen P.L., Rensen S.S.: The gut microbiota of nonalcoholic fatty liver disease: Current methods and their interpretation. Hepatol. Int., 2015; 9: 406-415

[65] Szewczyk A., Witecka A., Kiersztan A.: The role of gut microbiota in the pathogenesis of neuropsychiatric and neurodegenerative diseases. Postępy Hig. Med. Dośw., 2019; 73: 865-886

[66] Jones L.A., Sun E.W., Martin A.M., Keating D.J.: The everchanging roles of serotonin. Int. J. Biochem. Cell Biol., 2020; 125 105776

[67] Yaghoubfar R., Behrouzi A., Ashrafian F., Shahryari A., Moradi H.R., Choopani S., Hadifar S., Vaziri F., Nojoumi S.A., Fateh A. i wsp.: Modulation of serotonin signaling/metabolism by Akkermansia muciniphila and its extracellular vesicles through the gutbrain axis in mice. Sci. Rep., 2020; 10: 22119

[68] Macia L., Nanan R., Hosseini-Beheshti E., Grau G.E.: Host- and microbiota-derived extracellular vesicles, immune function, and disease development. Int. J. Mol. Sci. 2019; 21: 107

[69] Han E.C, Choi S.Y., Lee Y., Park J.W., Hong S.H., Lee H.J.: Extracellular RNAs in periodontopathogenic outer membrane vesicles promote TNF- $\alpha$ production in human macrophages and cross the blood-brain barrier in mice. FASEB J., 2019; 33: 13412-13422

[70] Olson C.A., Vuong H.E., Yano J.M., Liang Q.Y., Nusbaum D.J., Hsiao E.Y.: The gut microbiota mediates the anti-seizure effects of the ketogenic diet. Cell, 2018; 173: 1728-1741.e13
[71] Kang D.W., Adams J.B., Gregory A.C., Borody T., Chittick L., Fasano A., Khoruts A., Geis E., Maldonado J., McDonough-Means S. i wsp.: Microbiota transfer therapy alters gut ecosystem and improves gastrointestinal and autism symptoms: An open-label study. Microbiome, 2017; 5: 10

[72] Kraeuter A.K., Guest P.C., Sarnyai Z.: The Y-maze for assessment of spatial working and reference memory in mice. Methods Mol. Biol., 2019; 1916: 105-111

[73] Ou Z., Deng L., Lu Z., Wu F., Liu W., Huang D., Peng Y.: Protective effects of Akkermansia muciniphila on cognitive deficits and amyloid pathology in a mouse model of Alzheimer's disease. Nutr. Diabetes, 2020; 10: 12

[74] Michalovich D., Rodriguez-Perez N., Smolinska S., Pirozynski M., Mayhew D., Uddin S., Van Horn S., Sokolowska M., Altunbulakli C., Eljaszewicz A. i wsp.: Obesity and disease severity magnify disturbed microbiome-immune interactions in asthma patients. Nat. Commun., 2019; 10: 5711

[75] Farrokhi A.S., Darabi N., Yousefi B., Askandar R.H., Shariati M., Eslami M.: Is it true that gut microbiota is considered as panacea in cancer therapy? J. Cell. Physiol., 2019; 234: 14941-14950

[76] Routy B., Le Chatelier E., Derosa L., Duong, C.P., Alou, M.T., Daillère R., Fluckiger A., Messaoudene M., Rauber C., Roberti M.P. i wsp.: Gut microbiome influences efficacy of PD-1-based immunotherapy against epithelial tumors. Science, 2018; 359: 91-97 